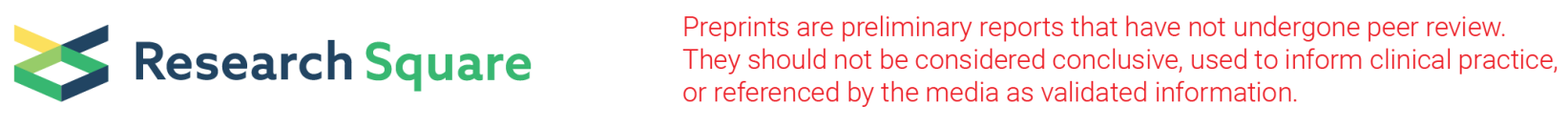

\title{
Neonatal Circumcision: Public Health Necessity or Ethical Dilemma? - Systematic Review
}

Brian J. Morris ( $\square$ brian.morris@sydney.edu.au )

University of Sydney

\section{Beth Rivin}

Gadjah Mada University

John N. Krieger

University of Washington

\section{Research Article}

Keywords: Circumcision male, Circumcision neonatal, Ethics, Legal, Male health, Human rights, Evidence-based medicine; Anticircumcision, Sexual function; PRISMA

Posted Date: November 30th, 2021

DOI: https://doi.org/10.21203/rs.3.rs-1083676/v1

License: @ (i) This work is licensed under a Creative Commons Attribution 4.0 International License. Read Full License 


\section{Abstract}

Male circumcision $(\mathrm{MC})$ is common in many countries. Despite clear health benefits, ethical arguments have been invoked opposing MC, especially when performed neonatally (NMC). NMC is when most MCs are performed in developed countries. Here we provide the first PRISMA-compliant systematic review of the disparate evidence of ethical and legal arguments concerning NMC and MC of older boys. Searches were performed of PubMed, Embase and Scopus for publications relevant to ethical and legal aspects of MC in developed Anglophone and European countries. This led to retrieval of 48 articles meeting the inclusion criteria. A further 18 articles and 16 Internet publications were identified from searches of bibliographies of articles retrieved. Two more were supplied by a legal academic colleague. In total 84 publications were reviewed. The literature revealed arguments by some that parent-approved MC of a nonconsenting child is unethical. But parental consent also applies to vaccination and all other medical therapies in children. Strong data support a conclusion that: (1) NMC is low risk, (2) NMC provides immediate and lifetime medical and health benefits, and (3) NMC has no adverse effect on sexual function and pleasure. The United Nations Convention on the Rights of the Child articulates the right to health and focuses on the best interests of the child as its guiding principle. Discouraging or denying $M C$ to neonates is arguably unethical, given the overwhelming health benefits. Legal scholars regard case-law as supporting the legality of NMC. Ethical and legal arguments support the rights of males of all ages to lifetime protection against infection and diseases caused by lack of MC. Arguments opposing NMC generally involve distortion of the medical evidence, poorly designed studies and opinions. Opposition to NMC goes against the principles of evidencebased medicine used in reviews conducted to develop pediatric policies in support of optimum public health, sexual health, mental health, and human rights.

\section{Background}

Surgical removal of the foreskin (male circumcision, MC) is common, global prevalence being $37-39 \%$ [1]. In the US, $91 \%$ of non-Hispanic whites, $76 \%$ of Afro-American blacks, and $44 \%$ in Hispanics are circumcised [2] as compared with $10-20 \%$ in other Anglophone countries [1]. In these settings the procedure generally takes place early in infancy (neonatal MC, NMC). MC has been performed for thousands of years by various cultures worldwide [3]. In ancient times, prevention of foreskin inflammation and sexual problems stemming from phimosis might explain why diverse societies worldwide implemented $\mathrm{MC}$, with the practice becoming a ritual cultural or religious practice [3]. Implementation in patriarchal societies would be unlikely if $\mathrm{MC}$ had a detrimental effect on penile function or sexual pleasure. By preventing foreskin-related problems that are impediments to erection, $\mathrm{MC}$ may have facilitated intercourse and therefore procreation, with implications for tribal strength and resilience [3,4]. In recent times health reasons have increasingly come to the fore as a reason for NMC [5].

Medical MC arose in Victorian times, when it was found to reduce risk of syphilis [6], as well as various other sexually transmitted infections (STIs) [7], balanitis [7], phimosis [7,8], paraphimosis [7], preputial adhesions [8], poor hygiene [7] and cancer [9].

The prevalence of adverse medical conditions that can be partially or almost completely mitigated by NMC is variable, as is their morbidity and risk of mortality. Extensive reviews by the American Academy of Pediatrics (AAP) [10,11], and the US Centers for Disease Control and Prevention (CDC) [12,13], and the Circumcision Academy of Australia (CAA) [14] concluded that NMC benefits outweigh the risks. The CDC and CAA quantified this as 100 to 1 in favour. The AAP noted that cultural factors might take precedence for some families when deciding whether to request MC for a son. The AAP's stance was followed by a significant $49 \%$ increase in proportion of NMCs in US hospitals [15].

Most common are urinary tract infections (UTI). The CDC review [13] referred to the most recent meta-analysis of UTI involving 22 studies, mostly in the US [16]. This found NMC reduced UTI in infant males by 10-fold. In uncircumcised infant boys, UTI prevalence is $1 \%$, representing $~ 100,000$ UTIs annually in the US, $90 \%$ of which would have been prevented by NMC [16]. The meta-analysis estimated that lifetime UTI prevalence is $32.1 \%$ in uncircumcised males compared with $8.8 \%$ in the circumcised [16].

Phimosis is universal in newborn boys, gradually decreasing with age to $3.4 \%(95 \% \mathrm{Cl} 1.8-6.6)$ in males aged $\geq 18$ years, as found in a recent systematic review [17]. Paraphimosis is less common, but is regarded as a medical emergency because constriction of the penile shaft can cause gangrene [18]. Inflammation (balanitis and balanoposthitis) is also common, and was found in a meta-analysis to be $68 \%$ lower in circumcised males [19]. Penile candidiasis is common in balanitis and has a $40 \%$ higher prevalence uncircumcised men [20].

Circumcision protects against heterosexual acquisition of HIV. This was confirmed in data from high-quality randomized controlled trials (RCTs) [21-24], that led the World Health Organization (WHO) and UNAIDS to endorse the roll out of voluntary medical MC (VMMC) 
programs in sub-Saharan Africa [25,26]. To date over 20 million procedures have been performed in high-priority countries [27], accompanied by substantial reductions in HIV infections [28]. HIV risk reduction in recent meta-analyses of all studies was 70\% [29] and $72 \%$ [30].

Data from RCTs and numerous observational studies has found that MC reduces the risk of various STIs, such oncogenic genotypes of human papillomavirus (HPV), herpes simplex virus type 2 (HSV-2), Trichomonas vaginalis, Mycoplasma genitalium, Treponema pallidum, Haemophilus ducreyi, as well as candidiasis (see reviews: [5,11,13,31-34]).

Another risk from being uncircumcised is penile cancer, which in the US has a lifetime risk of is approximately 1 in 1,000 in uncircumcised men [35], making it uncommon, but not rare. In contrast, penile cancer risk in an circumcised man is 22-fold lower [36] and is regarded as rare [19,36,37], being particularly low for men circumcised early in life [38]. Meta-analyses found that phimosis, balanitis and smegma increase penile cancer risk 12-, 3.8- and 3.0 fold, respectively [19]. Another meta-analysis found oncogenic HPV genotypes were present in $47 \%$ of penile cancers [39]. A meta-analysis [40] and RCTs [41-46] found MC reduces the risk of oncogenic HPV infection by one-third. This degree of risk reduction is similar to what HPV vaccines afford against penile cancer [47]. Penile cancer often requires total or partial penectomy, toxic combinations of chemotherapy and radiotherapy, lymphadenectomy, and can cause debilitating lymphoedema, urinary difficulties, impaired mental well-being, sexual dysfunction and risk of death [37].

Risk of prostate cancer is on average $10 \%$ lower in circumcised men, as found in meta-analyses [48-50]. Early MC reduced risk by $17 \%$ in a US study [51] and by $14 \%$ in a Canadian study [52]. Based on lifetime risk of prostate cancer of 1 in 8 (12.5\%), $2.1 \%$ of US men would be spared from prostate cancer if circumcised in childhood [50].

Women with uncircumcised male partners are at increased risk of cervical cancer, cervical dysplasia, oncogenic HPV infection, genital warts, HSV-2, genital ulcer disease, Chlamydia trachomatis, Neisseria gonorrhoea, Trichomonas vaginalis, Hemophilus ducreyi, HIV, bacterial vaginosis, Mycoplasma genitalium, Candidiasis, dysuria, and vaginal discharge, as documented in systematic reviews [53,54]).

Sexual function, sensation and pleasure is not adversely affected by MC, as shown by compelling data, including from studies of men whose MC took place in infancy [55]. (see RCT data [56,57], systematic reviews [58-63], meta-analyses [59,60], a large British probability survey [64], physiological studies [65], and histological correlates showing that penile neuroreceptors involved in sexual pleasure are mostly located in the corona and underside of the shaft near the frenulum, with none in the foreskin $[62,66,67]$. Of all parts of their penis, men ranked the foreskin last for erogenous sensation [68]. The most recent meta-analysis found that uncircumcised men are more likely to experience erectile problems and pain during intercourse [60].

Because NMC involves surgery on a non-consenting minor, with parents providing proxy consent, some claim that it is unethical. Individuals and organizations opposed to $\mathrm{MC}$ of boys argue against scientific findings and evidence-based policies supporting the rights of parents to choose NMC for their newborn son as a desirable medical and public health measure for prophylaxis against a wide array of common and uncommon medical conditions and diseases. To undermine the evidence favouring NMC, opponents recite a compendium of claims.

The aims of the present article were to (1) perform a systematic review of the ethics and legal aspects of medical MC, particularly of circumcision of boys in socio-economically advanced Anglophone and European countries, (2) determine the number of cases of adverse medical conditions averted over the lifetime for each annual US birth cohort, and (3) examine arguments opposing MC of boys, whether these might be tenable in the broad context of public health and whether or not the public health benefits of NMC outweigh ethical concerns.

\section{Methods}

\section{Search strategy}

Following PRISMA guidelines [69], we performed literature searches of PubMed, EMBASE, SCOPUS and Cochrane databases to identify articles published in English from 2 Jan 2000 to 1 Nov 2021 on ethical and legal aspects of MC particularly NMC and MC of older boys in developed socio-economically advantaged Anglophone and European countries. Keywords for searches of PubMed were "circumcision male ethical", "circumcision male ethics", and "circumcision male legal." EMBASE and Cochrane searches used "circumcision ethics" and "circumcision law". SCOPUS searches used "circumcision male ethics" and "circumcision male law". Each search result was copied into a Word document. 
Figure 1 shows the PRISMA-compliant search strategy performed. Titles and abstracts were screened, and the full text of each potentially suitable article was then examined by BJM and JNK independently to determine whether the article met the inclusion criteria above. Reference lists and related article links of eligible studies were searched to identify additional studies potentially suitable for inclusion.

\section{Results And Discussion Search results}

Figure 1 summarizes results of sequential database searches, in which articles already retrieved were not included again. PubMed searches using "circumcision male ethical" yielded 355 hits, "circumcision male ethics" yielded 354 hits, and "circumcision male legal" yielded 109 hits. EMBASE searches for "circumcision" and "ethics" yielded 186 hits and for "circumcision" and "law" 48 hits. SCOPUS searches using "circumcision male ethics" yielded 266 hits and "circumcision male law" 56 hits. Cochrane gave no hits. Examination of PubMed results for "circumcision male ethical" identified 34 articles that satisfied the inclusion criteria [70-102], using "circumcision male ethics" 8 more [103-110], and "circumcision male legal" a further 5 [111-115]. No further articles were identified in EMBASE searches. The SCOPUS search for "circumcision male ethics" identified 1 more article [116]. Searches of bibliographies of the articles retrieved, identified 18 additional articles [110,117-133] and 16 relevant Internet publications [134-149]. Two more were kindly suggested by an academic law colleague who read our manuscript $[150,151]$. In total, searches yielded 84 publications for inclusion.

\section{Ethics and human rights}

Despite the medical evidence of benefits, philosophical arguments claiming that NMC, and MC of older children, is unethical persist $[74,80,82,85,135,152]$. Rather than a calm, nuanced discourse, arguments by NMC opponents have sometimes been emotive $[74,75,119,135,153]$. Here we discuss the ethical pros and cons.

Scholarly assessments have suggested that MC of male minors is ethical [86-91,107]. Given the wide-ranging protection that MC provides against multiple medical conditions and infections in infancy and childhood, including STIs in adolescent males who engage in sexual activity early, it has been argued that it would be unethical to leave boys uncircumcised [88,90]. In this regard, the following statement appears in Article 24 of the UN Convention on the Rights of the Child (CRC): "States Parties recognize the right of the child to the enjoyment of the highest attainable standard of health ... States Parties shall strive to ensure that no child is deprived of his or her right of access to such health care services" [120]. Article 24 of the CRC articulates the definition of health to include preventative health care and, thus, the CRC supports the interpretation that rights of the child would be violated if NMC were not advised and offered as standard practice. In fact, this statement might logically be interpreted as mandating NMC, since not circumcising boys is prejudicial to their health [90].

The arguments by Jacobs \& Arora [90] led to a response by Darby, a well-published opponent of boyhood MC [92]. Although he was "happy to agree with their proposal," he paraphrased it as, "the only situation in which [ritual infant MC] can be ethically or legally permissible is where it is performed hygienically in a hospital by an accredited mohel or other qualified operator, using full anaesthesia, accompanied by the prescribed ceremonies and prayers in accordance with ritual requirements." Jacobs \& Arora disagreed, stating that "adequate anaesthesia does not necessitate general anaesthesia" (which carries inherent risk), "the earlier circumcision is performed the safer it is," "as physicians, we routinely counsel parents regarding the risk versus benefit calculus in making medical and surgical decisions," "it is of utmost importance to acknowledge the quality of the data in this conversation - a point that is often overlooked by critics of circumcision," and that for greater safety, "in the United States, most Islamic circumcisions are performed during infancy," rather than later, when "pain, safety, and extent of the procedure" are different [93].

Opponents have used as support a document by the International NGO (non-government organization) Council on Violence against Children (ICVAC) [136]. But this devotes only one of its 48 pages (page 22) to MC. Although noting the WHO's support for MC in protection against HIV, it ignores the additional, wide-ranging medical benefits of NMC that start in infancy. The ICVAC quotes from the 2010 Royal Dutch Medical Association (KNMG)'s MC policy developed by ethicist Gert van Dijk declaring that the procedure can be delayed until the boy is old enough to give consent [154]. The KNMG policy does not, however, consider the scientific evidence. The ICVAC cites outdated reports in Kenya, Norway and Germany that have failed to translate into legislation, if anything the reverse (see below).

Opponents cite Article 24(3) of the United Nations (UN) Convention on the Rights of the Child [120], because this section surmises that

"States Parties shall take all effective and appropriate measures with a view to abolishing traditional practices prejudicial to the health of 
children." Although many cultures support the tradition of NMC, it certainly can be considered a medical intervention that respects and protects a child's right to health, based on all the evidence. Moreover, the UN's WHO published a comprehensive 140-page "Manual for early infant male circumcision under local anaesthesia" [155]. UNESCO, an agency of the UN, supports NMC.

Rather than a violation of human rights, Vawda and Maqutu argue that NMC is justifiable as a public health necessity, stating "in the face of the compelling evidence available it would be foolhardy to forego this important intervention in the fight against the rampant HIV/AIDS pandemic. Limiting the rights of neonates under such circumstances can be regarded as a justifiable measure to protect the public health" [123].

A claim by opponents that childhood MC is harmful and that children have a "right to health" [124] appears ironic, when risk-benefit analyses favour NMC benefits by at least 100 to one, and that over their lifetime approximately half of uncircumcised males will experience an adverse medical condition attributable to their foreskin $[31,33]$. The meta-ethical approach of science is primarily utilitarian, seeking to decide which decision will most likely produce the greatest net benefit. Well-informed public health authorities should be persuaded by the evidence that on balance favours NMC. That is the position taken by the AAP, CDC and CAA (see above).

\section{Autonomy and self-determination}

A core feature of the anti-MC agenda focuses on the ethical discourse about the child's human right to bodily integrity. Jacobs summarized this view as, "To the extent that notions of autonomy are comprehensible, autonomy is held to be a trump card, so that a minor breach of genital physical integrity outweighs all other considerations of right and interest" [156].

Opponents claim that $\mathrm{MC}$ has no benefits, only harms, and argue against scientific findings and evidence-based policies supporting the rights of parents to choose NMC for a newborn son as a desirable public health measure $[72-74,81,83,100,104,105,111,112,157]$.They further argue that, even if there are benefits, they only apply to males who are old enough to decide for themselves whether or not to get circumcised, or that the benefits are insufficient to merit the procedure [72-74,83,102-105,118]. A systematic review evaluating the various claims found them to be based on speculation or misinformation [106]. In the current "post-truth" era, vocal minority groups consider their opinions more important than medical and scientific experts [158]. Such attitudes fit with a pattern of radical individualism, devaluation of scientific evidence, and promotion of autonomy. For example, despite the potential consequences, parents may reject medical advice and refuse to allow their children to be vaccinated.

All rights of the neonate must be balanced. In this case, self-determination must be balanced against the right to health, but opponents of NMC claim there are no benefits and therefore do not engage in this important perspective. We believe that the right to health trumps selfdetermination of the neonate. There are numerous examples in public health that support the right to health over other individual rights. For instance, health regulations, such as vaccine requirements for school entry and life in general in response to the Covid-19 pandemic are good examples of society deciding that the right to personal and public health takes precedence over individual rights to selfdetermination.

According to the Brussels Collaboration on Genital Integrity (BCGI) [121], an intervention to alter a bodily state is medically necessary when it poses a threat to the person's well-being. Given the degree and breadth of benefits conferred by NMC, NMC accords with the BCBI's statement.

According to international human rights law, as articulated in the Convention on the Rights of the Child (Article 5):

"States Parties shall respect the responsibilities, rights and duties of parents or, where applicable, the members of the extended family or community as provided for by local custom, legal guardians or other persons legally responsible for the child, to provide, in a manner consistent with the evolving capacities of the child, appropriate direction and guidance in the exercise by the child of the rights recognized in the present Convention." In other words, the newborn does not have the capacity to make the important decision about NMC, but the parents, extended family or community within the cultural context will make the decision with the best interests of the child in mind. The cultural context is very important, as the Australian Family Law Council recognised about MC in its discussion of female socalled "circumcision", in stating, item 2.54,"In Australia, male circumcision is not unlawful. It has religious significance to persons of particular religious persuasions, such as those of Jewish faith. It is also understood to be performed as an initiation rite on males entering adulthood in some Aboriginal communities" [150]. Beyond Australia, other religions and cultures practice circumcision as part of their cultural identity, such as in Islam and by Coptic Christians [159]. 
Balancing rights can be challenging. However, our position is that the right to the highest attainable standard of health, including the right to preventive health care trumps arguments about other rights [117]. And as for "autonomy," arguments opposing MC on the basis of the child's right to bodily integrity and future autonomy have been refuted by authorities in ethics [87,89-91,107-109]. It has in fact been argued that being circumcised boosts autonomy more than constraining it [94].

It has been argued that " 'bodily integrity' is an ambiguous notion that cannot be 'applied' in practice," and "can be overridden by competing moral obligations, for example to obey God's law [in Judaism and Islam] or to contribute to the health of the patient" [160]. In evaluating MC and autonomy, McMath et al. argue that "bodily integrity is a prima facie principle in its own right, closely connected with, but fundamentally different from, the principle of personal autonomy" and that "we should be idealists when evaluating the child's own interests, but realists when evaluating public health justifications for circumcision" [161].

\section{Legal arguments}

A broad gamut of legal arguments used by MC opponents were extensively evaluated by experts in public health and ethics (Table 1). Some of the authors were professors of law, bioethics, medicine, medical sciences and public health $[88,110,117]$. The reviews provided an extensive compendium of reasons in support of the legality and ethical justification for the circumcision of male children.

Jeffrey Brown, a member of the AAP committee on medical Liability and Risk Management, noted that physicians may be held accountable for not telling parents about the benefits and risks of interventions for their child such as vaccination and circumcision [162]. Regarding NMC, Brown stated that this may apply to UTIs in uncircumcised infants and STIs in sexually active minors [162]. He also pointed out that risks and costs are lowest for NMC and benefits are highest, further arguing against waiting for the boy to make the "circumcision decision" for himself when he is older. Brown's arguments differ from the somewhat fanciful and spurious arguments by Darby who appeared intent on preserving the foreskin at all costs [104].

In a Minnesota District Court lawsuit against Mercy Hospital, NMC opponent, Robert Van Howe, provided an Affidavit in support of a case in which a boy experienced complications after having been circumcised soon after birth [139]. In the judgement, the court criticized Van Howe's evidence, calling it "confusing," as well as "inconsistent and self-contradictory." The case, including all six counts, was dismissed.

NMC opponents have lobbied to have bans introduced for MC of minors in the US [163] and northern European countries [77]. This led to parliamentary debates and campaigns by Jewish and Muslim organizations, eventually upholding the right of families to have their boys circumcised safely [125]. To date none of the efforts to impose bans have succeeded [79,95,141,142].

As one example, in Germany in 2012, a Court in Cologne considered a bleeding complication case involving a Muslim doctor who circumcised a Muslim boy [143]. The outcome was misconstrued by news media and MC opponents as Germany having imposed a ban on MC. Instead, the Court had ruled the illegality of MC to be among the, "... undecided questions of law ...," concluding that the defendant was not guilty of a criminal act (see the full English translation [144]). He was acquitted and costs ordered to be borne by public funds. An appeal by the prosecution failed. The Bundestag (German Parliament) then enacted legislation upholding the legal right of parents to choose MC for their sons for religious or other reasons so long as it was Critics claimed the law was political [81]. Parentally approved $\mathrm{MC}$ of boys in a hospital by "knowledgeable staff" is also legal in France [113].

Another example is a recommendation by a law body in Tasmania that non-therapeutic MC of male children should be banned [145]. In response, a legal and medical evaluation by a lawyer and academics concluded that "doctors should be allowed to perform medical procedures based on sound evidence of effectiveness and safety with guaranteed protection. Parents should be free to act in the best interests of the health of their infant son by having him circumcised should they choose" [88].

Opponents have equated MC with ritual "female genital mutilation" (FGM), most forms of which are anatomically dissimilar to MC [102]. Despite the lack of similarity, some opponents refer to MC as "male genital mutilation" [75], a term that appears self-serving. Opponents misconstrued a FGM case in the UK [100] by failing to note that items 72 and 73 of the judgement recognized substantial health benefits of boyhood MC that differentiated it from FGM [146]. For a critical evaluation of the judgement by Sir James Munby, see McAllister [114].

Russell, a general practitioner in Brisbane, Australia, stated that "any person who is advised against, or denied circumcision on spurious grounds, who then goes on to suffer from one of the conditions which might reasonably have been prevented or minimised by circumcision, has a right to damages against the person who advised against or denied circumcision on spurious grounds" [164]. 


\section{Professional ethics and the Hippocratic Oath}

In referring to NMC, opponents quote the Hippocratic Oath as stating "First, do no harm." Abbasi regarded it as, "an ancient oath true in spirit but impossible to practise in the messy business of modern healthcare” [127]. The Greek text $\nabla \varphi \varepsilon \lambda \dot{\varepsilon} \varepsilon$ เv poorly and inappropriately translated into Latin as "primum non nocere." The passage from the Hippocratic treatise on Epidemics (First book, second part, paragraph 5) actually states, "I will apply the regimens of treatment according to my ability and judgment for the benefit of my patients and protect them from harm and injustice" [128]. The Oath also contains the statement, "I will prevent disease whenever I can, for prevention is preferable to cure" [129,147]. NMC would thus appear to accord with the Hippocratic Oath. The argument by $\mathrm{MC}$ opponents also assumes that $\mathrm{MC}$ constitutes harm, thereby assuming beforehand the very thing that opponents claim, thus introducing circularity into their argument.

Followers of the Hippocratic method (Hippocratics) were strictly physicians and did not perform surgery. These days even general practitioners perform minor surgery such as NMC. Initially every surgical intervention begins by doing harm in the cutting, manipulation, excision and, for older males, stitching needed. After healing, it is expected that the intervention will have been useful. Any 'harm' from NMC is minor and temporary at most.

\section{Consent}

Decisions about health in the newborn period necessitate involvement by the parents or legal guardians. Parents make decisions and consent to all medical therapies and interventions for their children, including vaccinations. NMC is no different. The ethical principle of autonomy and its application as informed consent is central to the decision-making. Based on full information of risks and benefits of the procedure, parents voluntarily consent for their newborn. When presented with overwhelming evidence of benefits compared to the risks, parents will typically act in the best interests of their children. AAP Task Force bioethicist Douglas Diekema provided a summary of the issues and consent process [71]. These were used in the AAP policy recommendations [10,11]. Information leading up to informed consent for NMC should include the following facts: (a) numerous common conditions prevented or substantially reduced by NMC pose a risk to the health and well-being of the boy during infancy and childhood, (b) the procedural risks are 10-20 times lower (0.4\%) for NMC compared with MC in childhood and beyond [11,165], (c) NMC avoids the need to seek specialist treatment for later foreskin disease, (d) costs of later MC often for medical need and for treatment of a wide array of conditions that NMC protects against are substantially higher [47,166-172], and (e) other factors favour the newborn period of life over MC later in childhood, adolescence or adulthood (Table 3).

The issue of consent is a common argument by NMC opponents [74,111]. Myers \& Earp posit that "medically unnecessary penile circumcision ... should not be performed on individuals who are too young to provide meaningful consent to the procedure" [74]. Unfortunately, rather than detailed systematic reviews of the medical evidence, they relied on selectively citated low quality publications by themselves and other NMC opponents. They failed to cite published data showing that without NMC at least half of males will, over their lifetime, experience one or more adverse medical conditions that are partially or completely mitigated by NMC, nor that benefits of NMC in protection against these exceed the risks by at least 100 to $1[31,33,173]$.

The consent process for NMC is based upon the principles of mutual trust, shared responsibility and understanding between the physicians and parents, as well as a document outlining the procedure, goals, risks, benefits and expected outcomes [174].

\section{Best time}

NMC is preferred because early in life circumcision is simple, quick, low risk, less expensive, post-procedural healing is generally complete within a week, cosmetic outcome is usually good, and is convenient when compared with the barriers and other drawbacks posed by MC of older boys and men (Table 2) [175]. Nevertheless, MC at any age requires a well-trained, competent surgeon, who can be a family physician/general practitioners, and the use of pain relief, preferably by local anaesthesia, and other considerations advised by the AAP in its recommendations $[10,11]$. 


\section{Consequences of NMC for disease prevalence in the US and Australia}

It was shown recently that an increase in early MC prevalence in Australia from the current level of $18.75 \%$ [176] to 90\% would result in $\sim 77,000$ fewer cases of adverse medical conditions over the lifetime per annual birth cohort [177]. For the US, we calculated that if infant MC rates reported for non-Hispanic white males [2] decreased from the $90 \%$ to a level of $10 \%$, the approximate number of various adverse medical conditions over their lifetime per annual birth cohort of 1.57 million males would increase by over one million (Table 3 ).

\section{Arguments opposing circumcision of boys}

\section{Historical evidence}

We agree with arguments by opponents that benefits of $\mathrm{MC}$ in disease prevention touted in Victorian and early $20^{\text {th }}$ century publications [178-180] were based on weak evidence and anecdotes, with some claims being fanciful.

\section{Current evidence of medical benefits justify access}

The quality of evidence confirming protection against risk of STIs, phimosis, balanitis and penile cancer has improved substantially [17,19,36,181-184], and in recent decades has been extended to UTIs [16], HIV and other STIs such as high-risk HPV [185] (see Background).

A particular challenge to arguments by opponents was posed by the "gold-standard" of high-quality evidence, namely the large welldesigned RCTs in 2005 and beyond. Nevertheless, opponents attempted to undermine the trial findings [152,186-191]. Critical evaluation of their claims by medical scientists and clinical academics exposed numerous flaws in the arguments used [192-200].

Opponents then shifted their focus by acknowledging that MC for heterosexual HIV prevention may apply in sub-Saharan African settings in which HIV prevalence is high and MC prevalence in some countries and cultures is low. They continued to argue that MC does not apply in the US where most infections occur in men who have sex with men (MSM) and in intravenous drug users who share needles. Such claims are undermined by data from the US [201], Europe and Israel [202], India [203-205] and Asia [206], showing that circumcised heterosexual men in these settings are at lower risk of heterosexual HIV infection. In Northern American and European settings most HIV infections occur in MSM, particularly those that adopt the receptive role during anal intercourse [207] for which MC would offer no protection. Calculations by two of the present authors [208] explain why recent studies found HIV and other STIs were not significantly lower in circumcised men $[209,210]$.

After considering the evidence, the AAP recommended that parents and guardians should be informed about the medical benefits and risks of NMC prior to the birth of the child, and that the evidence justified access for families who choose it $[10,11]$.

\section{Procedural risks}

Procedural risks posed by $\mathrm{MC}$ are emphasized by NMC opponents. While devastating penile injuries can occur during MC, they are extremely rare. The AAP policy in 2012 , based on data available at the time, noted that frequency of minor adverse events was $0.5 \%$, all of which were easily treated and usually led to complete resolution. In contrast, the incidence of serious complications requiring hospital admission was only $0.02 \%$ [11]. Similarly, a study by mostly CDC researchers in 2014 of 1.4 million MCs in the US found an adverse event frequency of $0.4 \%$ for NMC [165], similar to previous reports [165,211]. Adverse event frequencies were 10-20 times higher for MC of older boys and males aged $\geq 10$ years [165]. Citing an analysis in Mayo Clinic Proceedings [31], the CDC stated that benefits of NMC exceed risks by, "100:1" [13].

\section{Sexual health}

This has been another target of claims by MC opponents. A recent extensive systematic review of all of the evidence for and against such claims concluded that the consensus of the highest-quality literature is that MC, including NMC, has minimal or no adverse effect, and in some studies benefits [60], on sexual function, sensation, satisfaction and pleasure for males circumcised neonatally or in 
adulthood [63]. The evidence for adult MC was supported by RCTs [56,57]. MC opponents then argued that effects of MC on sexual function and pleasure do not apply to men circumcised in infancy. It would of course be impractical and ethically questionable to conduct a RCT of the effect on NMC on sexual function and pleasure later in life. The arguments used by opponents were largely based on anecdotes or low-quality surveys. In one US survey by MC opponents, circumcised men reported higher satisfaction with their MC status than did uncircumcised men [212]. Curiously, instead of accepting the findings at face value, the authors suggested that circumcised men held false beliefs by refusing to accept that they had been harmed by their NMC. Multiple flaws in the study were identified [213].

\section{Psychological sequelae}

Some MC opponents argue that pain experienced during NMC results in permanent damage to vulnerable neuronal sensory structures in neonates, and that, as a result, the sexual experience of neonatally circumcised men is diminished [74]. Such views, which are abundant on the Internet and in social media [214], may be read and believed by men with sexual problems who are too embarrassed to consult a medical practitioner for advice and effective treatment $[63,215]$. Men with normal sexual function may also succumb to the arguments, causing them to think that their sex life has been diminished, with resultant anxiety and resentment of their parents' decision to have them circumcised. A systematic review found a strong correlation between depression and sexual dysfunction [216]. The distress caused by belief in the erroneous narrative may therefore have detrimental effects on men's sexual function and mental health [215].

Parents' decision to have a newborn son circumcised may be to ensure his penis appears similar to that of his peers when older. An lowa survey of undergraduate males aged $17-24$ years, $87 \%$ of whom were circumcised, found that most locker room penile teasing concerned penis size (75-83\%) [217]. But being uncircumcised accounted for $24 \%$ of teasing. In Sweden, where almost all males are uncircumcised, apart from slight shyness in the change-room, a study of schoolboys circumcised for phimosis a decade earlier found no adverse psychological effect [218].

\section{Further misunderstandings by MC opponents}

MC opponents tend to have little or no medical or biological knowledge, as evident for a false claim [74] that in infancy the foreskin is "fused" to the shaft skin leading to "degloving" (i.e., removal of shaft skin with the foreskin) during NMC [219]. In reality, as discussed above, any serious complications of medical NMC in countries such as the US are rare. Small studies in various countries, often involving ritual MC by medically untrained individuals, have reported higher prevalence of adverse events, including severe complications [220].

In a $B M J$ "Head to Head" article, Geoff Hinchley argued against infant MC in an emotive, one-sided manner replete with fallacies [75]. In contrast, Kirsten Patrick argued in favour of infant MC, pointing to the overriding medical benefits compared with low risks, so justifying parental choice [76].

As further support for the impermissibility of paediatric MC, Myers \& Earp argued that "it is unethical for a doctor or other healthcare provider to handle a child's genitals beyond what is strictly necessary for diagnosis or treatment" [74]. Given the benefits of the simple procedure of NMC, and the strict ethical principles that medical practitioners must adhere to, their argument appears extreme. They argued that the foreskin should not be removed at birth because the owner might later want to have it used to construct a "neovagina" during gender reassignment surgery [74]. But only 12.5 per 100,000 such men seek a male to female procedure [221]. Furthermore, not all want a neovagina, and there are other options for circumcised men who do [222].

NMC opponents have also argued against surgery for hypospadias repair in boys [223]. Hypospadias is a relatively common congenital abnormality in which the urethral opening forms on the underside of the penis, meaning difficulties with urination, physical problems, and later sexual problems [224]. Just as NMC, boys under 5 years of age have no recollection of the surgery [225], whereas older boys and men do.

Instead of MC, steroid creams can be used to treat phimosis and penile inflammation [226]. This approach is far from ideal [184,227]. It requires commitment to regular application and long-term steroid use may have side-effects. [228]. Steroid treatment for 2 (range 1-23) months was only $35 \%$ effective during 4 (range 1.5-60) months follow-up in a recent meta-analysis of the very serious foreskin-related inflammatory condition, lichen sclerosus [227]. In contrast, treatment by MC is almost $100 \%$ effective [229]. Preputioplasty can be used, but is less effective as a cure than MC, and serves to accommodate the wishes of those patients who want to preserve their foreskin [230]. Recurrence after preputioplasty is not uncommon, circumcision then being provided [231]. 
It has been suggested that the risk of UTI in boys does not warrant NMC for prevention because oral antibiotics can be used [74,77,103]. However, oral administration in infants is difficult and absorption is low, requiring hospitalization to enable intravenous antibiotic administration $[79,232]$. Emergence of resistance to most or all antibiotics, including methicillin, is making treatment of UTI more challenging [233-238]. Furthermore, maternal antibiotic use during pregnancy increases the risk of resistant pathogens in neonatal UTI [239]. Sub-preputial swabs found 50 bacterial isolates, mostly multi-drug-resistant strains, in boys aged 7 days to 11 years [240]. Among boys aged 2 months to 9 years 72 microorganisms, including 54 gram-positive bacteria (57\% enterococcus species), 17 gramnegative bacteria (41\% Escherichia coli) and Candida species, were identified [241]. Potentially uropathogenic gram negative rods were present in $17 \%$ of uncircumcised vs. $4 \%$ of circumcised healthy young men [242]. Streptococci, strict anaerobes and genital mycoplasmas were only present in the uncircumcised [242]. A RCT found that MC significantly reduced both the prevalence and load of genital anaerobic bacteria [243].

Thus, the increased quantity and quality of medical evidence over the years has rendered arguments opposing MC, including NMC, on medical grounds unconvincing [106]. Opposition to MC of boys has now retreated to considerations of a more philosophical nature. Parents of a newborn son should be made aware of the barriers and other reasons against not making an affirmative "circumcision decision" (Table 2).

Whether an older boy or man is circumcised or uncircumcised, he may resent his parents' decision. Given the barriers to MC at an older age, uncircumcised males may wish they had been circumcised in infancy, whereas circumcised males might think they are missing out on something by not having a foreskin.

Having decided to get circumcised, a man might tend to approve of the outcome of his decision, just as may be the case for a circumcised man who decides to undergo "foreskin restoration," which is "a very burdensome and time-consuming process that, if successful, creates a pseudo-prepuce only" [74] (see footnote 130 of the latter reference). The futility of such an enterprise is because the same or greater sexual satisfaction was evident in most cohort studies comparing men who were circumcised with those who were not, irrespective of the age at which their MC took place. Moreover, in the circumcised penis, the most erogenous regions - the glans and distal ventral shaft - would, during sexual intercourse, have direct contact with the vaginal wall, and such contact has been suggested to enhance sexual pleasure [244].

Individuals opposed to MC may hold unscientific beliefs, and may adhere to disproven (even fabricated [245,246]) claims and speculative ideas [106]. Denial of science is not new, but in the digital age evidence-based conclusions are increasingly being threatened by beliefs based on emotion and isolated anecdotes. In this, the post-truth era, facts are disputed, with science deniers utilizing pervasive social media to air their views, so presenting a challenge for scientists [247]. As the late US Senator Daniel Patrick Moynihan was fond of saying, "Everyone is entitled to their own opinion, but not their own set of facts" [248].

\section{Psychological consequences of belief in a questionable ideology}

As well as adversely affecting psychologically vulnerable men, claims by opponents may mislead such men into thinking that symptoms they may be experiencing are due to their NMC when, in fact, their symptoms are due to medical or psychological problems.

Consequently, by blaming their NMC, not only might they suffer undue anxiety, those men may not address the real cause of their problem, whether it be medical or psychological. And, as discussed above, men who need the procedure for medical reasons may be deterred from consulting with a medical practitioner, thereby unnecessarily prolonging, or exacerbating, their problem.

The fundamental principle of cognitive-behavioural psychology, espoused by the ancient Greek philosopher, Epictetus, is: It is not so much what happens to a person that matters, but their view of it. In the so-called "A-B-C model," A is the activating event, B is the belief about the event, and $\mathrm{C}$ is the emotional and behavioural consequence of the belief. For example, although delayed ejaculation can occur in men irrespective of their MC status, other things being equal, if delayed ejaculation were caused by NMC, that could be viewed in a negative light by some, whereas others might view it as a benefit. In essence, some "problems" might only be problems because they are construed as such. Once men have been persuaded that their NMC is a cause of their sexual problems, other psychological processes come into play. Confirmation bias is one, i.e., looking for and acceptance of only that which agrees with the person's belief, and rejection of anything that does not.

\section{The vaccination analogy}

Page $10 / 26$ 
Similarities between anti-NMC proponents and anti-vaccination activists are evident. Each involve an intervention being performed on a neonate, infant or child, pain (reduced by local anaesthetic), risk of adverse events (albeit low), medical ignorance about the intervention and its consequences, and proxy consent having to be given by the parents or guardians rather than the individual, so potentially raising ethical and legal issues. For NMC, additional issues are that minor surgery is involved, and that NMC and MC of older boys has the potential to fuel prejudice because in Europe, most of Asia and some other countries the intervention is practiced by religious and cultural minorities. The consequences of not circumcising early, like not vaccinating early, are greater likelihood of avoidable infections, disease, suffering and deaths.

UTI prevalence in circumcised infant males is up to one-tenth that in infants not circumcised [16,249]. Number needed to treat (NNT) to prevent UTI by NMC was reported as 39, decreasing to 29 when other sequelae were included [249]. In comparison, for influenza vaccination of children, NNT is 50 [250]. UTI in infancy can result in significant morbidity [251] and is the most common cause of sepsis in male neonates [211]. Within the first 2 years incidence of pyelonephritis (0 vs. 0.67), kidney disease (0.063 vs. 0.13 ), hypertension ( 0.031 vs. 0.27 ), and vesicoureteral reflux (0.13 vs. 0.27 ) per 100 person-years was lower in 2,334 neonatally circumcised vs. 573 uncircumcised US infant males, respectively [249]. Rate for all diagnoses combined was 0.65 vs. 3.5, respectively $(p<0.0001)$ [249]. Progression to renal damage occurred in $19 \%$ of children with UTI aged $<2$ years [252].

In defending the legality of NMC, Millard and Goldstuck state, "Many of the preventive interventions that we routinely recommend for our patients have some degree of risk, but we recommend them when scientific evidence clearly demonstrates that the benefits outweigh the risks. Immunisations are a good example of this practice" [253]. In the current era of rollout of vaccines against SARS-CoV-2, side effects have been well publicized, but are generally accepted because the benefits of vaccination far outweigh the risks.

According to Hainz, "circumcision should be subsumed under human enhancement and treated like other enhancement technologies" [254]. And that "prohibition appears to be unjustified because it would deprive parents of the possibility of providing their children with protection (although not total) against various diseases." Hainz suggested that "maybe circumcision is on a par with other interventions that alter the nature of humans but are usually regarded as permissible or even recommended or obligatory, such as vaccination," and "The permanent and irreversible removal of the foreskin appears not to be less radical than a form of enhancement of children that is widely accepted: vaccination." But "ethically speaking, circumcision for religious intentions is unacceptable," especially when some forms of religious circumcisions involve dangerous practices such as metztitzah b'peh." He imagines "the institutional advocacy of alternatives to circumcision as soon as these alternatives exist. This would be a compromise between permission and prohibition that would also be justified by the subsumption strategy."

In an emotive, one-sided comparison, Myers \& Earp argued that risks from vaccination are trivial, involving a possible "allergic skin reaction," whereas risks from MC are catastrophic, since MC causes "a genital skin laceration" [74].

\section{Risk compensation}

The suggestion that, once circumcised, men would forego condom use is contradicted by meta-analyses that found no difference in condom use for up to 2 years after MC [255,256]. Unlike condoms, MC is a one-off procedure that does not require future compliance each time a man has sexual intercourse. The same applies to vaccination. Besides the hepatitis $\mathrm{B}$ vaccine, the only vaccines widely used for STI prevention are ones that protect against up to 9 of 20 or so HPV genotypes that infect the genital region. MC contrasts with condoms for protection against STIs because condoms must be applied at each sexual encounter. MC and condom use each provide a reasonable degree of protection against STIs. When both are in place protection is higher [196].

Public health advice generally advises adoption of a package of proven preventive measures rather than a subset to maximize impact. HPV vaccination of girls early in high school can help reduce risk of cervical cancer, but uptake is variable across settings, current vaccines do not protect against all high-risk HPV genotypes, and long-term durability of effectiveness remains to be seen. The switch from pap smears to primary screening for HPV in high-income countries, by a PCR-based test invented by the first author and a colleague [257,258], will improve risk detection, but is not practicable in resource-constrained settings.

\section{Death}

The worst adverse outcome of MC is death. As an example of the death comparison, in Canada, where approximately half of males are circumcised, over the period 1992-2004 only 3 deaths were attributed to NMC [259] and only 3 to vaccination [260]. There were 38 cases 
of anaphylaxis, 37 cases of convulsions, and 4 brain infections attributable to vaccination. Like NMC, benefits of childhood vaccination greatly outweigh the risks. In Canada, in comparison to deaths from NMC, there were 43 deaths from penile cancer [261], 3,708 annual deaths from prostate cancer and 443 from cervical cancer [261]. The evidence, summarized in Background, shows that NMC reduces risk of each of these diseases.

\section{Criticisms of AAP and CDC Policy Statements}

The trend in policy statements in recent years has been towards an increase in support for NMC. Such a trend is evident in AAP and CDC policies.

Criticisms of the 2012 AAP infant MC policy [10,11] as "culturally biased" by Danish anti-MC campaigner, Frisch, with co-authors mostly in Northern Europe [130], were dismissed by the AAP Task Force [116]. The AAP authors argued that, if anything, the evidence pointed to cultural bias in Europe rather than in the USA. The AAP Task Force called for respectful dialogue stating "this debate and the academic literature are demeaned when those with an ideological agenda disseminate inaccurate information, misapply scientific principles, make accusations that are unsupported, communicate in a vitriolic tone, and attempt to discredit and mischaracterise alternative views and those who hold them. Healthy debate and dialogue should be encouraged, but attempts to mislead and discredit have no place in the academic literature" [96]. Criticisms of the AAP policy by others [97] were shown to be flawed because the criticisms were "based on a poor understanding of epidemiology, erroneous interpretation of the evidence, selective citation of the literature, statistical manipulation of data, and circular reasoning" [98]. Instead, "Considering the totality of the evidence, the AAP's policy could be criticized for being too conservative" [98]. Svoboda \& Van Howe then attempted to defend their arguments [131], but the evidence undermined their defence [148]. Criticisms of the AAP's policy by Darby [105] were also found to lack merit [132].

In a discussion of the AAP's 2012 infant MC policy statement, AAP Task Force member Michael Brady pointed out that "any decision about the role of newborn male circumcision in the delivery of optimal healthcare to children should not be high jacked [sic!] by those who have emotional or subjective beliefs about this procedure' [99]. He argued against suggestions by MC opponents that MC be delayed until age 18 years to 'allow the male to participate in the decision making process," since "many of the health benefits that can be achieved by circumcision are lost if the procedure is deferred to age 18 years." As part of this he pointed to the high frequency of sexual activity and acquisition of STIs by US teens, with $47 \%$ of twelfth grade students having had sexual intercourse and $24 \%$ more than 4 different sexual partners [149]. He stated that the AAP felt that "not providing parents with appropriate information concerning health benefits of circumcision would actually be unethical." While "the opponents feel that this decision should not be left up to the parents .... clearly parents consistently make decisions for their children based on what they believe are in the best interest of their child.' The AAP Task Force 'did not believe that this healthcare decision should be denied to those individuals who could not afford to pay for it on their own. For that reason, we feel that third party payers including Medicaid should reimburse for newborn male circumcision. Cost should not be a factor in whether or not parents make their decision to circumcise or not circumcise their child." Moreover, "Given the clear evidence of health benefit, and a benefit that outweighs the risks, and the fact that some religions include circumcision as one of their traditional rites, it is unlikely that legislation to ban circumcision would be passed or upheld as constitutional in the United States.'

In response to the CDC's released a draft policy statement released in 2014 for peer-review and public comments [262,263], MC opponents published criticisms in journal articles. These were found to be flawed by academic and medical authorities [117,264,265]. The CDC's final 82 page review with 389 references was released in 2018 [12,13], along with detailed responses to peer review [266] and to numerous public comments it received, mostly from MC opponents [267]. Criticisms by the opponents were dismissed as flawed by the CDC. A key conclusion was, "In a comprehensive risk-benefit analysis of infant male circumcision based on reviews of the literature and meta-analyses, it is estimated that over a lifetime, benefits exceed risks by a factor of 100:1" [13].

Legal, ethical and human rights arguments were mounted by anti-MC lawyers Adler [133] and Svoboda [77] attempting to undermine the CDC's draft MC policy recommendations [262,263]. Adler's criticisms were found to be "flawed scientifically, ethically and legally, and [that they] should be dismissed as endangering public health and individual well-being" [117]. Criticisms by ethicist Earp [82] were similarly shown to be flawed [264]. Criticisms by Frisch \& Earp [226] were similarly repudiated [110].

Vogelstein evaluated stance-taking by medical bodies [101]. He found that because the stance taken by the AAP in support of the circumcision of boys is based largely on scientific data demonstrating that the benefits outweigh the risks it should be accepted because, unlike its detractors, "the AAP plausibly has the bona fides to pronounce upon this issue" and is "likely to be correct" [101]. He went on to state that while some regard the issue as controversial, it fits best with being a "false controversy" given that "any arguments for [at least

Page $12 / 26$ 
one position on the issue] are so poor, or opposing arguments are so strong (given available information and evidence) that those who hold such a view must be unreasonable in doing so" [101]. Van Howe disputed Vogelstein's stance mostly with arguments used previously [84] that were refuted by others [97].

Less rigorous NMC reviews by the Canadian Paediatric Society [268], were found to be flawed [32]. As was the case for BMA's guidance [269] in a critique [34].

The latest Royal Australasian College of Physicians (RACP) Division of Paediatrics and Child Health policy in 2010 [270] was, like previous policies, ideologically opposed to NMC because of an attempt to change the culture [271]. RACP Fellows with expertise in public health, men's health and STIs, and Fellows of other medical bodies found the policy to not be evidence-based [272]. The Royal Dutch Medical Association's policy, developed by an ethicist, claims NMC is a violation of children's rights," refers only to "complications" of the procedure, and urges "a strong policy of deterrence" [154]. Similarly, the Danish Medical Association declared that NTMC is "ethically unacceptable" [273].

\section{Conclusions}

On balance, medical NMC and MC at any age by competent practitioners should be regarded as ethical and consistent with the right to health. Belief in unscientific arguments opposing $\mathrm{MC}$ have the potential to drive down $\mathrm{MC}$ rates and thereby result in increases of adverse medical conditions and burden to health systems. Disease prevention by safe NMC and MC at any age is central to the affirmative evidence-based policy recommendations of the AAP and the CDC. Evidence-based policies have now raised the bar, meaning that medical organizations globally can no longer rely on opinions, but must consider the extensive high-quality scientific evidence as an integral part of NMC policy development and recommendations. Unless as seems unlikely, any new valid argument against NMC emerges, it would appear the time has come for acceptance of NMC as an important ethically-and legally supported public health intervention.

\section{Abbreviations}

AAP, American Academy of Pediatrics, CDC, Centers for Disease Control and Prevention; ICVAC, International NGO (non-government organization) Council on Violence against Children; IIEF, International Index of Erectile Function; MC, male circumcision, NMC, neonatal male circumcision; RCT, randomized controlled trial, UTI, urinary tract infection; STI, sexually transmitted infection.

\section{Declarations}

\section{Ethics approval and consent to participate}

Not applicable as this study did not include any human subjects as it was a review of the current literature.

\section{Consent for publication}

Not applicable for this manuscript as it does not contain potentially identifiable participant information.

\section{Availability of data and materials}

All data generated or analysed during this study are included in this published article.

Results of publication database searches used during the current study available from the corresponding author on reasonable request. The journal articles supporting the conclusions of this review are cited and are available on their respective journal's websites. Copyright laws prevents us from making these articles freely available.

\section{Competing interests}

BJM is a member of the Circumcision Academy of Australia, a not-for-profit, government registered, medical society that provides evidence-based information on male circumcision to parents, practitioners and others, as well as contact details of doctors who perform the procedure. JNK is co-inventor of a circumcision device patented by University of Washington. He has not received any income from this. BR declares that she has no competing interests. The authors have no religious or other affiliations that might influence the topic of MC. 


\section{Funding}

There were no sources of funding for this study.

\section{Authors' contributions}

BJM conceptualized this study and developed the protocols and data collection instruments in accordance with PRIMSA guidelines. BJM performed the initial screening and reviewed and determined which articles met study inclusion criteria. BJM, BR and JNK completed a qualitative analysis, extracting the major themes. All authors contributed substantially to revising this article critically for important intellectual content. All authors read and approved the final manuscript.

\section{Acknowledgements}

None

\section{Email addresses of authors}

brian.morris@sydney.edu.au; brivin@uw.edu; jkrieger@uw.edu

\section{References}

1. Morris BJ, Wamai RG, Henebeng EB, et al. Estimation of country-specific and global prevalence of male circumcision. Popul Health Metr.2016;14:article 4 (13 pages).

2. Introcaso CE, Xu F, Kilmarx PH, Zaidi A, Markowitz LE. Prevalence of circumcision among men and boys aged 14 to 59 years in the United States, national health and nutrition examination surveys 2005-2010. Sex Transm Dis.2013;40(7):521-525.

3. Cox G, Morris BJ. Why circumcision: From pre-history to the twenty-first century, Chapter 21. In: Surgical Guide to Circumcision. edn. Edited by Bolnick DA, Koyle MA, Yosha A. London: Springer; 2012: 243-259

4. Cox G. De virginibus, puerisque. The function of the human foreskin considered from an evolutionary perspective. Med Hypoth.1995;45:617-621.

5. Tobian AA, Gray RH. The medical benefits of male circumcision. JAMA.2011;306:1479-1480.

6. Hutchinson J. On the influence of circumcision in preventing syphilis. Med Times Gazette.1855;II:542-543.

7. Anonymous AA. Circumcision. Edinburgh Med J.1874;20(3):282.

8. Sayre LA. On the deleterious effects of a narrow prepuce and preputial adhesions. Transactions of the Ninth International Medical Congress.1888;IIl:20 pages https://collections.nlm.nih.gov/ext/dw/101283080/PDF/101283080.pdf (accessed Jul 16, 2021).

9. Hutchinson J. A plea for circumcision. Arch Surg.1890;2:15 (reprinted in Br Med J 27 Sep 1890, p. 1769).

10. American Academy of Pediatrics Task Force on Circumcision. Circumcision policy statement. Pediatrics.2012;130(3):585-586.

11. American Academy of Pediatrics Task Force on Circumcision. Male circumcision. Pediatrics.2012;130(3):e756-e785.

12. Centers for Disease Control and Prevention. Information for providers counseling male patients and parents regarding male circumcision and the prevention of HIV infection, STIs, and other health outcomes https://stacks.cdc.gov/view/cdc/58456

13. Centers for Disease Control and Prevention. Background, Methods, and Synthesis of Scientific Information Used to Inform "Information for Providers to Share with Male Patients and Parents Regarding Male Circumcision and the Prevention of HIV Infection, Sexually Transmitted Infections, and other Health Outcomes" https://stacks.cdc.gov/view/cdc/58457

14. Morris BJ, Wodak AD, Mindel A, et al. Infant male circumcision: An evidence-based policy statement. Open J Prevent Med.2012;2:7992.

15. Many BT, Rizeq YK, Vacek J, et al. A contemporary snapshot of circumcision in US children's hospitals. J Pediatr Surg.2020;55(6):1134-1138.

16. Morris BJ, Wiswell TE. Circumcision and lifetime risk of urinary tract infection: a systematic review and meta-analysis. J Urol.2013;189(6):2118-2124.

17. Morris BJ, Matthews JG, Krieger JN. Prevalence of phimosis in males of all ages: Systematic review. Urology.2020;135:124-132.

18. Vunda A, Lacroix LE, Schneider F, Manzano S, Gervaix A. Videos in clinical medicine. Reduction of paraphimosis in boys. N Engl J Med.2013;368(13):e16. 
19. Morris BJ, Gray RH, Castellsague X, et al. The strong protective effect of circumcision against cancer of the penis. Adv Urol.2011;2011:article 812368.

20. Ferris JA, Richters J, Pitts MK, et al. Circumcision in Australia: further evidence on its effects on sexual health and wellbeing. Aust N Z J Public Health.2010;34(2):160-164.

21. Auvert B, Taljaard D, Lagarde E, Sobngwi-Tambekou J, Sitta R, Puren A. Randomized, controlled intervention trial of male circumcision for reduction of HIV infection risk: The ANRS 1265 Trial. PLoS Med.2005;2(e298):1112-1122.

22. Bailey RC, Moses S, Parker CB, et al. Male circumcision for HIV prevention in young men in Kisumu, Kenya: a randomised controlled trial. Lancet.2007;369(9562):643-656.

23. Gray RH, Kigozi G, Serwadda D, et al. Male circumcision for HIV prevention in men in Rakai, Uganda: a randomised trial. Lancet.2007;369(9562):657-666.

24. Siegfried N, Muller M, Deeks JJ, Volmink J. Male circumcision for prevention of heterosexual acquisition of HIV in men. Cochrane Database Syst Rev.2009;Issue 2(2):CD003362.

25. World Health Organization and Joint United Nations Program on HIV/AIDS. Male circumcision: Global trends and determinants of prevalence, safety and acceptability. 2007. http://whqlibdoc.who.int/publications/2007/9789241596169_eng.pdf (accessed Jul 12, 2021)

26. World Health Organization and UNAIDS. New data on male circumcision and HIV prevention: policy and programme implications. http://who.int/hiv/mediacentre/MCrecommendations_en.pdf(accessed Jul 12, 2021)

27. World Health Organization. Remarkable progress in the scale up of voluntary medical male circumcision as an HIV prevention intervention in 15 ESA countries: UNAIDS and WHO, 2019. (accessed Sep 30, 2020)

28. Borgdorff MW, Kwaro D, Obor D, et al. HIV incidence in western Kenya during scale-up of antiretroviral therapy and voluntary medical male circumcision: a population-based cohort analysis. Lancet HIV.2018;5(5):e241-e249.

29. Lei JH, Liu LR, Wei Q, et al. Circumcision status and risk of HIV acquisition during heterosexual intercourse for both males and females: A meta-analysis. PLoS One.2015;10(5):e0125436.

30. Sharma SC, Raison N, Khan S, Shabbir M, Dasgupta P, Ahmed K. Male circumcision for the prevention of human immunodeficiency virus (HIV) acquisition: a meta-analysis. BJU Int.2018;121(4):515-526.

31. Morris BJ, Bailis SA, Wiswell TE. Circumcision rates in the United States: rising or falling? What effect might the new affirmative pediatric policy statement have? Mayo Clin Proc.2014;89(5):677-686.

32. Morris BJ, Klausner JD, Krieger JN, Willcox BJ, Crouse PD, Pollock N. Canadian Paediatrics Society position statement on newborn circumcision: a risk-benefit analysis revisited. Can J Urol.2016;23(5):8492-8502.

33. Morris BJ, Kennedy SE, Wodak AD, et al. Early infant male circumcision: Systematic review, risk-benefit analysis, and progress in policy. World J Clin Pediatr.2017;6(1):89-102.

34. Morris BJ, Krieger JN. Non-therapeutic male circumcision. Paediatr Child Health.2020;30:102-107.

35. Kochen M, McCurdy S. Circumcision and the risk of cancer of the penis. A life-table analysis. Am J Dis Child.1980;134(5):484-486.

36. Schoen EJ, Oehrli M, Colby C, Machin G. The highly protective effect of newborn circumcision against invasive penile cancer. Pediatrics.2000;105(3):E36.

37. Thomas A, Necchi A, Muneer A, et al. Penile cancer. Nat Rev Dis Primers.2021;7(1):11.

38. Daling JR, Madeleine MM, Johnson LG, et al. Penile cancer: importance of circumcision, human papillomavirus and smoking in in situ and invasive disease. Int J Cancer.2005;116:606-616.

39. Albero G, Castellsague X, Giuliano AR, Bosch FX. Male circumcision and genital human papillomavirus: a systematic review and meta-analysis. Sex Transm Dis.2012;39(2):104-113.

40. Zhu YP, Jia ZW, Dai B, et al. Relationship between circumcision and human papillomavirus infection: a systematic review and metaanalysis. Asian J Androl.2017;19(1):125-131.

41. Backes DM, Bleeker MC, Meijer CJ, et al. Male circumcision is associated with a lower prevalence of human papillomavirusassociated penile lesions among Kenyan men. Int J Cancer.2012;130(8):1888-1897.

42. Gray RH, Serwadda D, Kong X, et al. Male circumcision decreases acquisition and increases clearance of high-risk human papillomavirus in HIV-negative men: a randomized trial in Rakai, Uganda. J Infect Dis.2010;201(10):1455-1462.

43. Senkomago V, Backes DM, Hudgens MG, et al. Acquisition and persistence of human papillomavirus 16 (HPV-16) and HPV-18 among men with high-HPV viral load infections in a circumcision trial in Kisumu, Kenya. J Infect Dis.2015;211(5):811-820.

Page 15/26 
44. Tobian AAR, Serwadda D, Quinn TC, et al. Male circumcision for the prevention of HSV-2 and HPV infections and syphilis. N Engl $J$ Med.2009;360:1298-1309.

45. Wilson LE, Gravitt $P$, Tobian AA, et al. Male circumcision reduces penile high-risk human papillomavirus viral load in a randomised clinical trial in Rakai, Uganda. Sex Transm Infect.2013;89(3):262-266.

46. Auvert B, Sobngwi-Tambekou J, Cutler E, et al. Effect of male circumcision on the prevalence of high-risk human papillomavirus in young men: results of a randomized controlled trial conducted in Orange Farm, South Africa. J Infect Dis.2009;199:14-19.

47. Morris BJ, Mindel A, Tobian AAR, et al. Should male circumcision be advocated for genital cancer prevention? Asian Pacific J of Cancer Prev.2012;13(9):4839-4842.

48. Pabalan N, Singian E, Jarjanazi H, Paganini-Hill A. Association of male circumcision with risk of prostate cancer: a meta-analysis. Prost Cancer Prostatic Dis.2015;18(4):352-357.

49. Li YD, Teng Y, Dai Y, Ding H. The association of circumcision and prostate cancer: A meta-analysis. Asian Pacific $\mathrm{J}$ of Cancer Prev.2016;17(8):3823-3827.

50. Morris BJ, Matthews JG, Pabalan N, Moreton S, Krieger JN. Male circumcision and prostate cancer: A meta-analysis re-visited. Can J Urol.2021;28(4):10768-10776.

51. Wright JL, Lin DW, Stanford JL. Circumcision and the risk of prostate cancer. Cancer.2012;118(18):4437-4443.

52. Spence AR, Rousseau MC, Karakiewicz PI, Parent ME. Circumcision and prostate cancer: a population-based case-control study in Montreal, Canada. BJU Int.2014;114(6b):E90-98.

53. Grund JM, Bryant TS, Jackson I, et al. Association between male circumcision and women's biomedical health outcomes: a systematic review. Lancet Glob Health.2017;5(11):e1113-e1122.

54. Morris BJ, Hankins CA, Banerjee J, et al. Does male circumcision reduce women's risk of sexually transmitted infections, cervical cancer and associated conditions? (Systematic Review). Front Public Health.2019;7:article 4.

55. Chinkoyo E, Pather M. Erectile function in circumcised and uncircumcised men in Lusaka, Zambia: A cross-sectional study. Afr J Prim Health Care Fam Med.2015;7(1).

56. Kigozi G, Watya $S$, Polis $\mathrm{CB}$, et al. The effect of male circumcision on sexual satisfaction and function, results from a randomized trial of male circumcision for human immunodeficiency virus prevention, Rakai, Uganda. BJU Int.2008;101(1):65-70.

57. Krieger JN, Mehta SD, Bailey RC, et al. Adult male circumcision: effects on sexual function and sexual satisfaction in Kisumu, Kenya. J Sex Med.2008;5(11):2610-2622.

58. Morris BJ, Krieger JN. Does male circumcision affect sexual function, sensitivity, or satisfaction?-A systematic review. J Sex Med.2013;10(11):2644-2657.

59. Tian Y, Liu W, Wang JZ, Wazir R, Yue X, Wang KJ. Effects of circumcision on male sexual functions: a systematic review and metaanalysis. Asian J Androl.2013;15(5):662-666.

60. Yang Y, Wang X, Bai Y, Han P. Circumcision does not have effect on premature ejaculation: A systematic review and meta-analysis. Andrologia.2018;50(2):e12851.

61. Shabanzadeh DM, Düring S, Frimont-Moller C. Male circumcision does not result in inferior perceived male sexual function - a systematic review. Dan Med J.2016;63(7):A5245.

62. Cox G, Krieger JN, Morris BJ. Histological correlates of penile sexual sensation: Does circumcision make a difference? Sex Med.2015;3(2):76-85.

63. Morris BJ, Krieger JN. The contrasting evidence concerning the effect of male circumcision on sexual function, sensation, and pleasure: A systematic review. Sex Med.2020;8(4):577-598.

64. Homfray V, Tanton C, Mitchell KR, et al. Examining the association between male circumcision and sexual function: evidence from a British probability survey. AIDS.2015;29(11):1411-1416.

65. Payne K, Thaler L, Kukkonen T, Carrier S, Binik Y. Sensation and sexual arousal in circumcised and uncircumcised men. J Sex Med.2007;4(3):667-674.

66. Halata Z, Munger BL. The neuroanatomical basis for the protopathic sensibility of the human glans penis. Brain Res.1986;371(2):205-230.

67. Garcia-Mesa Y, Garcia-Piqueras J, Cobo R, et al. Sensory innervation of the human male prepuce: Meissner's corpuscles predominate. J Anat.2021;239(4):892-902. 
68. Schober JM, Meyer-Bahlburg HF, Dolezal C. Self-ratings of genital anatomy, sexual sensitivity and function in men using the 'SelfAssessment of Genital Anatomy and Sexual Function, Male' questionnaire. BJU Int.2009;103:1096-1103.

69. Page MJ, McKenzie JE, Bossuyt PM, et al. The PRISMA 2020 statement: an updated guideline for reporting systematic reviews. BMJ.2021;372:n71.

70. Hodges FM, Svoboda JS, Van Howe RS. Prophylactic interventions on children: balancing human rights with public health. J Med Ethics.2002;28(1):10-16.

71. Diekema DS. Boldt v. Boldt: A pediatric ethics perspective. J Clin Ethics.2009;20(3):251-257.

72. Van Howe RS. Infant circumcision: the last stand for the dead dogma of parental (sovereignal) rights. J Med Ethics.2013;39(7):475481.

73. Merkel R, Putzke H. After Cologne: male circumcision and the law. Parental right, religious liberty or criminal assault? J Med Ethics.2013;39(7):444-449.

74. Myers A, Earp BD. What is the best age to circumcise? A medical and ethical analysis. Bioethics.2020;34(7):645-663.

75. Hinchley G. Is infant male circumcision an abuse of the rights of the child? (Head to Head article) BMJ.2007;335:1180.

76. Patrick K. Is infant male circumcision an abuse of the rights of the child? No. BMJ.2007;335:1181.

77. Svoboda JS, Adler PW, Van Howe RS. Circumcision Is unethical and unlawful. J Law Med Ethics.2016;44(2):263-282.

78. Garasic MD. In defence of male circumcision. Monash Bioeth Rev.2013;31(1):60-69.

79. Morris BJ, Tobian AA. Legal threat to infant male circumcision. JAMA Pediatr.2013;167(10):890-891.

80. Earp BD. The ethics of infant male circumcision. J Med Ethics.2013;39:418-420.

81. Aurenque D, Wiesing U. German law on circumcision and its debate: how an ethical and legal issue turned political. Bioethics.2015;29(3):203-210.

82. Earp BD. Do the benefits of male circumcision outweigh the risks? A critique of the proposed CDC guidelines. Front Pediatr.2015;3:18.

83. Di Pietro ML, Teleman AA, Di Pietro ML, Poscia A, González-Melado FJ, Panocchia N. Preventive newborn male circumcision: what is the child's best interest? Cuad Bioet.2017;28(94):303-316.

84. Van Howe RS. Response to Vogelstein: How the 2012 AAP Task Force on circumcision went wrong. Bioethics.2018;32(1):77-80.

85. Earp BD, Darby R. Circumcision, autonomy and public health. Public Health Ethics.2019;12(1):64-81.

86. Benatar M, Benatar D. Between prophylaxis and child abuse: The ethics of neonatal male circumcision. Am J Bioethics.2003;3(2):3548.

87. Benatar D, Benatar M. How not to argue about circumcision. Am J Bioethics.2003;3(2):W1-W9.

88. Bates MJ, Ziegler JB, Kennedy SE, et al. Recommendation by a law body to ban infant male circumcision has serious worldwide implications for pediatric practice and human rights. BMC Pediatr.2013;13:article 136.

89. Benatar D. Evaluations of circumcision should be circumscribed by the evidence. J Med Ethics.2013;39(7):431-432.

90. Jacobs AJ. The ethics of circumcision of male infants. Isr Med Assoc J.2013;15(1):60-65.

91. Jacobs AJ, Arora KS. Ritual male infant circumcision and human rights. Am J Bioeth.2015;15(2):30-39.

92. Darby R. The Mysterious Disappearance of the Object of Inquiry: Jacobs and Arora's Defense of Circumcision. Am J Bioeth.2015;15(5):70-72.

93. Jacobs AJ, Arora KS. Disappearance of the Object of inquiry: Jacobs and Arora's defense of circumcision". Am J Bioeth.2015;15(8):W4-5.

94. Brusa M, Barilan YM. Cultural circumcision in EU public hospitals - an ethical discussion. Bioethics.2009;23(8):470-482.

95. Stafford N. German ethics council backs religious circumcision if specific conditions met. BMJ.2012;345:e5789.

96. AAP TF. AAP Task Force on Circumcision 2012. The AAP Task Force on neonatal Circumcision: a call for respectful dialogue. J Med Ethics.2013:39:442-443.

97. Svoboda JS, Van Howe RS. Out of step: fatal flaws in the latest AAP policy report on neonatal circumcision. J Med Ethics.2013;39(7):434-441.

98. Morris BJ, Tobian AA, Hankins CA, et al. Veracity and rhetoric in paediatric medicine: a critique of Svoboda and Van Howe's response to the AAP policy on infant male circumcision. J Med Ethics.2014;40(7):463-470. 
99. Brady MT. Newborn male circumcision with parental consent, as stated in the AAP circumcision policy statement, is both legal and ethical. J Law Med Ethics.2016;44(2):256-262.

100. Fox M, Thomson M, Warburton J. Non-therapeutic male genital cutting and harm: Law, policy and evidence from U.K. hospitals. Bioethics.2019;33(4):467-474.

101. Vogelstein E. Professional hubris and its consequences: Why organizations of health-care professions should not adopt ethically controversial positions. Bioethics.2016;30(4):234-243.

102. Earp BD. Male or female genital cutting: why 'health benefits' are morally irrelevant. J Med Ethics.2021. Epub ahead of final Jan 18, 2021.

103. Svoboda JS. Circumcision of male infants as a human rights violation. J Med Ethics.2013;39(7):469-474.

104. Darby RJL. The child's right to an open future: is the principle applicable to non-therapeutic circumcision? J Med Ethics.2013;39(7):463-468.

105. Darby R. Risks, benefits, complications and harms: neglected factors in the current debate on non-therapeutic circumcision. Kennedy Inst Ethics J.2015;25(1):1-34.

106. Morris BJ, Moreton S, Krieger JN. Critical evaluation of arguments opposing male circumcision: A systematic review. J Evid Based Med.2019;12(4):263-290.

107. Bester JC. Ritual male infant circumcision: the consequences and the principles say yes. Am J Bioeth.2015;15(2):56-58.

108. Clark PA, Eisenman J, Szapor S. Mandatory neonatal male circumcision in Sub-Saharan Africa: medical and ethical analysis. Med Sci Monit.2007;13(12):RA205-213.

109. Mazor J. The child's interests and the case for the permissibility of male infant circumcision. J Med Ethics.2013;39(7):421-428.

110. Morris BJ, Krieger JN, Klausner JD, Rivin BE. The ethical course is to recommend infant male circumcision - Arguments disparaging American Academy of Pediatrics affirmative policy do not withstand scrutiny. J Law Med Ethics.2017;45(4):647-663.

111. Svoboda JS, Van Howe RS, Dwyer JG. Informed consent for neonatal circumcision: an ethical and legal conundrum. J Contemp Health Law Policy.2000;17(1):61-133.

112. Boyle GJ, Goldman R, Svoboda JS, Fernandez E. Male circumcision: pain, trauma and psychosexual sequelae. J Health Psychol.2002;7(3):329-343.

113. Gorgiard C, Rey-Salmon C. [Forensic issues raised by circumcision: Review and case report]. Arch Pediatr.2016;23(11):1153-1156.

114. McAlister RD. A dangerous muddying of the waters? The 'significant harm' of Re B and G (children) (Care Proceedings)[2015] EWFC 3. Med Law Rev.2016;24(2):259-267.

115. Bates B, Morris BJ. Legal arguments opposing infant male circumcision are flawed. Intern Med J.2012;42(11):1281-1282.

116. Task Force on Circumcision. Cultural bias and circumcision: the AAP Task Force on circumcision responds. Pediatrics.2013;131(4):801-804.

117. Rivin BE, Diekema DE, Mastroianni AC, Krieger JN, Klausner JD, Morris BJ. Critical evaluation of Adler's challenge to the CDC's male circumcision recommendations. Int J Child Rights.2016;24(2):265-303.

118. Testa P, Block WE. Libertarianism and circumcision. Int J Health Policy Manag.2014;3(1):33-40.

119. Denniston GC, Hodges FM, Milos MF. Male and Female Circumcision. Medical, Legal, and Ethical Considerations in Pediatric Practice. New York: Kluwer Academic / Plenum Publishers 1999.

120. United Nations Human Rights Office of the High Commissioner for Human Rights, Convention on the Rights of the Child. 44/25 20 November 1989.

http://www.ohchr.org/en/professionalinterest/pages/crc.aspx(http://www.un.org/documents/ga/res/44/a44r025.htm)

121. Brussels CGI. Brussels Collaboration on Genital Integrity. Medically unnecessary genital cutting and the rights of the child: Moving toward consensus. Am J Bioeth.2019;19(10):17-28.

122. Jacobs AJ. Is physical alteration a sufficient reason to prohibit ritual infant circumcision? J Relig Health.2021;60(3):1672-1693.

123. Vawda YA, Maqutu LN. Neonatal circumcision - violation of children's rights or public health necessity? S Afr J Bioethics Law.2011;4:36-42.

124. Hammond T, Carmack A. Long-term adverse outcomes from neonatal circumcision reported in a survey of 1,008 men: an overview of health and human rights implications. Int J Hum Rights.2017;21(2):189-218.

125. Aktürk S. Comparative politics of circumcision bans in western Europe: A causal narrative. APSA Preprints. 2019. https://preprints.apsanet.org/engage/apsa/article-details/5dc4273aa6490200117d2a04 (accessed 5 Nov, 2021)

Page $18 / 26$ 
126. Russell T. Non-circumcision a legal risk. Law in Practice.2005;Aug issue: http://www.circumcision.com.au/Further_Information/newsid374/371/Non-Circumcision-a-Legal-Risk.aspx.

127. Abbasi K. First no harm: the impossible oath. BMJ.2019;366:14734. https://www.bmj.com/content/366/bmj.I4734 (accessed Nov 3, 2021)

128. Retsas S. Rapid response to: First do no harm: the impossible oath. BMJ.2019;366:14734 https://www.bmj.com/content/4366/bmj.14734/rr-4732. (accessed Nov 3, 2021)

129. Kelishadi R. To the readers. Int J Prev Med.2010;1(1):i.

130. Frisch M, Aigrain Y, Barauskas V, et al. Cultural bias in the AAP's 2012 Technical Report and Policy Statement on male circumcision. Pediatrics.2013;131(4):796-800.

131. Svoboda SJ, Van Howe RS. Circumcision: A bioethical challenge. J Med Ethics.2014;eLetter(20 Jan).

132. Morris BJ, Krieger JN, Klausner JD. Critical evaluation of unscientific arguments disparaging affirmative infant male circumcision policy. World J Clin Pediatr.2016;5(3):251-261.

133. Adler PW. The draft CDC circumcision recommendations: Medical,ethical, legal, and procedural concerns. Int J Child Rights.2016;24(2):237-262.

134. Giving advice in a post-truth world. Acuity. https://www.acuitymag.com/opinion/giving-advice-in-a-post-truth-world (accessed Oct 29, 2021)

135. Earp BD. The unbearable assymetry of bullshit. Quillette. 2016. http://quillette.com/2016/02/15/the-unbearable-asymmetry-ofbullshit/ (last accessed Jan 19, 2021).

136. International NGO Council on Violence Against Children, Violating Children's Rights: Harmful Practices Based on Tradition, Culture, Religion or Superstition. (Last accessed Mar 12, 2021) Available at URL: https://resourcecentre.savethechildren.net/node/7212/pdf/7212.pdf. 2012.

137. WHO/UNAIDS/HPIEGO. Manual for male circumcision under local anaesthesia. 2006:http://www.who.int.hiv/topics/malecircumcision/en/. (accessed Oct 19, 2021)

138. Medical-legal risks associated with circumcision of newborn males: need for revised consent. AAP News. vol 34 , issue 4. http://www.aappublications.org/content/34/4/1.1?sso=1\&sso_redirect_count=1\&nfstatus=401\&nftoken=00000000-0000-00000000-000000000000\&nfstatusdescription=ERROR\%3a+No+local+token (accessed Oct 28, 2021)

139. District Court, Fourth Judicial District, state of Minnesota, County of Hennepin, File No. 27CV08-13968, M.L.G. vs. Dr. Natalie Zabezhinsky, M.D., et al., Memorandum Granting Defendant's Motion to Dismiss and Defendents' Motion for Summary Judgement http://www.circlist.com/circ-law/mcgunnigle.pdf (accessed 17 June 2021)

140. U.S. MGM Bill. http://www.mgmbill.org (accessed Nov 14, 2021)

141. California Assembly Bill 768. Male circumcision. http://legiscan.com/CA/text/AB768/id/348729 (accessed Jun 11, 2021) (http://legiscan.com/CA/text/AB768/id/348729)

142. DW news-service. Circumcision remains legal in Germany. http://www.dw.de/circumcision-remains-legal-in-germany/a-16399336 (accessed Jun 11, 2021)

143. District Court, Cologne. Landgericht Koln. 7 May 2012 Urteil 151 Ns 169/11. (http://www.justiz.nrw.de/nrwe/lgs/koeln/lg_koeln/j2012/)

144. District Court of Cologne - Judgement of 7 May 2012 on male circumcision for religious reasons. (Translation in English). Durham University news. (Last accessed Mar 12, 2019). https://www.dur.ac.uk/ilm/news/?itemno=14984

145. Tasmanian Law Reform Institute. Non-therapeutic male circumcision. Final report no 17, 2012. http://www.utas.edu.au/_data/assets/pdf_file/0006/302829/Non-Therapuetic-Circ_Final-Report-August-2012.pdf (accessed Jun $12,2021)$

146. Royal Courts of Justice. Sir James Munby. In the matter of B and G (Children) (No 2), Neutral Citation number: [2015] EWFC 3, Case Number LJ13C00295, 14 January 2015. https://www.judiciary.gov.uk/wp-content/uploads/2015/01/BandG_2_.pdf (accessed Jun 20, 2021)

147. Johns Hopkins University. Hippocratic Oath, Modern version. 2015. http://guides.library.jhu.edu/c.php?g=202502\&p=1335759 (accessed Jun 5, 2021).

148. Morris BJ. Reply to "Circumcision: A bioethical challenge" by Svoboda \& Van Howe. J Med Ethics https://jmebmjcom/content/40/7/463responses\#reply-to-circumcision-a-bioethical-challenge-by-svoboda--van-howe (accessed 21 
Jun 2021).2014.

149. Centers for Disease Control and Prevention. Trends in HIV-related risk behaviors among high school students - United States, 19912011. The Morbidity and Mortality Weekly Report 61, no. 29:556-560

https://www.cdc.gov/mmwr/preview/mmwrhtml/mm6129a4.htm?s_cid=mm6129a4_w (accessed June 21, 2021)

150. Attorney General. Female Genital Mutilation: A Report to the Attorney General. Canberra: Commonwealth Publishing House 1994.

151. Male circumcision: context, criteria and culture (Part 1).

https://www.unaids.org/en/resources/presscentre/featurestories/2007/february/20070226mcpt1 (accessed 8 Nov 2021)

152. Boyle GJ, Hill G. Sub-Saharan African randomized clinical trials into male circumcision and HIV transmission: Methodological, ethical and legal concerns. J Law Med.2011;19:316-333.

153. Fleiss PM, Hodges F. Neonatal circumcision does not protect against penile cancer. BMJ.1996;312(7033):779-780.

154. Royal Dutch Medical Association (KNMG). Non-therapeutic circumcision of male minors. Utrecht: Royal Dutch Medical Association (KNMG). http://knmg.artsennet.nl/Publicaties/KNMGpublicatie/Nontherapeutic-circumcision-of-male-minors-2010.htm (accessed Dec 20, 2018)

155. World Health Organization. Manual for early infant male circumcision under local anaesthesia. https://www.who.int/hiv/pub/malecircumcision/manual_infant/en/ (accessed Apr 7, 2021)

156. Jacobs AJ. Is physical alteration a sufficient reason to prohibit ritual Infant circumcision? J Relig Health.2021;60(3):1672-1673.

157. Svoboda JS. Nontherapeutic circumcision of minors as an ethically problematic form of iatrogenic injury. AMA J Ethics.2017;19(8):815-824.

158. Enfield N. Giving advice in a post-truth world. Acuity. 21 May, 2018. https://www.acuitymag.com/opinion/giving-advice-in-a-posttruth-world (accessed May 6, 2021)

159. Male circumcision: context, criteria and culture (Part 1). UNAIDS. Feb 26, 2007. https://www.unaids.org/en/resources/presscentre/featurestories/2007/february/20070226mcpt1 (accessed Nov 8, 2021)

160. Dekkers W, Hoffer C, Wils JP. Bodily integrity and male and female circumcision. Med Health Care Philos.2005;8:179-191.

161. McMath A. Infant male circumcision and the autonomy of the child: two ethical questions. J Med Ethics.2015;41(8):687-690.

162. Medical-legal risks associated with circumcision of newborn males: need for revised consent. AAP News, vol 34 , issue 4. http://www.aappublications.org/content/34/4/1.1?sso=1\&sso_redirect_count=1\&nfstatus $=401 \&$ nftoken $=00000000-0000-0000$ 0000-000000000000\&nfstatusdescription=ERROR\%3a+No+local+token (accessed Mar 8, 2019)

163. Federal Prohibition of Genital Mutilation Act. http://www.mgmbill.org (accessed Aug 20, 2021)

164. Russell CT. Non-circumcision a legal risk. Aust Doctor. 1996:Sep20:57.

165. El Bcheraoui C, Zhang X, Cooper CS, Rose CE, Kilmarx PH, Chen RT. Rates of adverse events associated with male circumcision in US medical settings, 2001 to 2010. JAMA Pediatr.2014;168(7):625-634.

166. Kacker S, Frick KD, Gaydos CA, Tobian AA. Costs and effectiveness of neonatal male circumcision. Arch Pediatr Adolesc Med.2012;166(10):910-918.

167. Sansom SL, Prabhu VS, Hutchinson AB, et al. Cost-effectiveness of newborn circumcision in reducing lifetime HIV risk among U.S. males. PLoS One.2010;5(1):article e8723.

168. Andrews AL, Lazenby GB, Unal ER, Simpson KN. The cost of Medicaid savings: the potential detrimental public health impact of neonatal circumcision defunding. Infect Dis Obstet Gynecol.2012;2012:article 540295 (540297 pages).

169. Ortenberg J, Roth CC. Projected financial impact of noncoverage of elective circumcision by Louisiana medicaid in boys 0 to 5 years old. J Urol.2013;190(4 Suppl):1540-1544.

170. Gutwein LG, Alvarez JF, Gutwein JL, Kays DW, Islam S. Allocation of healthcare dollars: analysis of nonneonatal circumcisions in Florida. Am Surg.2013;79(9):865-869.

171. Leibowitz AA, Desmond K, Belin T. Determinants and policy implications of male circumcision in the United States. Am J Public Health.2009;99(1):138-145.

172. Morris BJ, Bailis SA, Waskett JH, Wiswell TE, Halperin DT. Medicaid coverage of newborn circumcision: a health parity right of the poor. Am J Public Health.2009;99(6):969-971.

173. Morris BJ, Krieger JN. Non-therapeutic male circumcision. Paediatr Child Health (UK).2019;30(3):102-107.

174. Vemulakonda VM. Informed consent: Principles for elective circumcision. In: Surgical Guide to Circumcision. edn. Edited by Bolnick DA, Koyle MS, Yosha A. London: Springer-Verlag; 2012: 9-13.

Page 20/26 
175. Morris BJ, Waskett JH, Banerjee J, et al. A 'snip' in time: what is the best age to circumcise? BMC Pediatr.2012;12(1):article 20.

176. Qin KR, Paynter JA, Wang LC, Mollah T, Qu LG. Early childhood circumcision in Australia: Trends over 20 years and interrupted time series analysis. ANZ J Surg.2021;91(7-8):1491-1496.

177. Morris BJ, Wodak AD. Causes and consequences of the decline in circumcision in Australia. ANZ J Surg.2021;91(11):2546-2547.

178. Freeland EH. Circumcision as a preventative of syphilis and other disorders. Lancet.1900;156(4035):1869-1871.

179. Wolbarst AL. Universal circumcision as a sanitary measure. JAMA.1914;62:92-97.

180. Silby FA. Part II: boys. In: Youth and Sex Dangers and Safeguards for Girls and Boys. edn. Edited by Scharlieb M, Silby FA. London: Dodge Publishing Co.; 1913: 44-92.

181. Tobian AA, Kacker S, Quinn TC. Male circumcision: a globally relevant but under-utilized method for the prevention of HIV and other sexually transmitted infections. Ann Rev Med.2014;65:293-306.

182. Schoen EJ, Colby CJ, Ray GT. Newborn circumcision decreases incidence and costs of urinary tract infections during the first year of life. Pediatrics.2000;105(4 Pt 1):789-793.

183. Morris BJ, Hankins CA, Tobian AA, Krieger JN, Klausner JD. Does male circumcision protect against sexually transmitted infections? Arguments and meta-analyses to the contrary fail to withstand scrutiny. ISRN Urol.2014;2014:article 684706.

184. Morris BJ, Krieger JN. Penile inflammatory skin disorders and the preventive role of circumcision. Int J Prev Med.2017;8:32.

185. Castellsague X, Bosch FX, Munoz N, et al. Male circumcision, penile human papillomavirus infection, and cervical cancer in female partners. N Engl J Med.2002;346(15):1105-1112.

186. Van Howe RS, Storms MR. How the circumcision solution in Africa will increase HIV infections. J Publ Health Africa.2011;2(1 e4):1115.

187. de Camargo KR, Jr., de Oliveira Mendonca AL, Perrey C, Giami A. Male circumcision and HIV: a controversy study on facts and values. Glob Public Health.2013;8(7):769-783.

188. Darby R. Syphilis 1855 and HIV-AIDS 2007: Historical reflections on the tendency to blame human anatomy for the action of microorganisms. Glob Public Health.2015;10(5-6):573-588.

189. Green LW, McAllister RG, Peterson KW, Travis JW. Male circumcision is not the 'vaccine' we have been waiting for! Future HIV Ther.2008;2(3):193-199.

190. Van Howe RS. Circumcision as a primary HIV preventive: extrapolating from the available data. Glob Public Health.2015;10(5-6):607625.

191. Fish M, Shahvisi A, Gwaambuka T, Tangwa GB, Ncayiyana D, Earp BD. A new Tuskegee? Unethical human experimentation and Western neocolonialism in the mass circumcision of African men. Dev World Bioeth.2020:Epub ahead of print Sep11, 2020.

192. Wamai RG, Weiss HA, Hankins C, et al. Male circumcision is an efficacious, lasting and cost-effective strategy for combating HIV in high-prevalence AIDS epidemics: Time to move beyond debating the science. Future HIV Ther.2008;2(5):399-405.

193. Wamai RG, Morris BJ, Bailey RC, Klausner JD, Boedicker MN. Debating male circumcision for HIV prevention: a one-sided argument does not represent a legitimate 'controversy' analysis-reply to de Camargo et al. Glob Public Health.2015;10(5-6):672-678.

194. Wamai RG, Morris BJ, Waskett JH, et al. Criticisms of African trials fail to withstand scrutiny: male circumcision does prevent HIV infection. J Law Med.2012;20(1):93-123.

195. Morris BJ, Waskett JH, Gray RH, et al. Exposé of misleading claims that male circumcision will increase HIV infections in Africa. J Public Health Africa.2011;2(e28):117-122.

196. Morris BJ, Bailey RC, Klausner JD, et al. Review: a critical evaluation of arguments opposing male circumcision for HIV prevention in developed countries. AIDS Care.2012;24(12):1565-1575.

197. Morris BJ, Wamai RG, Krieger JN, Banerjee J, Klausner JD. Male circumcision to prevent syphilis in 1855 and HIV in 1986 is supported by the accumulated scientific evidence to 2015: Response to Darby. Glob Public Health.2017;12(10):1315-1333.

198. Morris BJ, Barboza G, Wamai RG, Krieger JN. Expertise and ideology in statistical evaluation of circumcision for protection against HIV infection. World J AIDS.2017;7:179-203.

199. Morris BJ, Barboza G, Wamai RG, Krieger JN. Circumcision is a primary preventive against HIV infection: Critique of a contrary metaregression analysis by Van Howe. Glob Public Health.2018;13(12):1889-1899.

200. Morris BJ. Voluntary medical male circumcision proves robust for mitigating heterosexual HIV infection. Clin Infect Dis.2021;73(7):e1954-e1956.

Page $21 / 26$ 
201. Warner L, Ghanem KG, Newman DR, Macaluso M, Sullivan PS, Erbelding EJ. Male circumcision and risk of HIV infection among heterosexual African American men attending Baltimore sexually transmitted disease clinics. J Infect Dis.2009;199(1):59-65.

202. Chemtob D, Op de Coul E, van Sighem A, Mor Z, Cazein F, Semaille C. Impact of Male Circumcision among heterosexual HIV cases: comparisons between three low HIV prevalence countries. Israel J Health Policy Res.2015;4(article 36):31-38.

203. Reynolds SJ, Shepherd ME, Risbud AR, et al. Male circumcision and risk of HIV-1 and other sexually transmitted infections in India. Lancet.2004;363:1039-1040.

204. Kenyon CR. HIV prevalence correlated with circumcision prevalence and high-risk sexual behavior in India's states: an ecological study. F1000Res.2019;8:60.

205. Dandona L, Kumar GA, Lakshmi V, et al. HIV incidence from the first population-based cohort study in India. BMC Infect Dis.2013;13:327.

206. Addanki KC, Pace DG, Bagasra O. A practice for all seasons: male circumcision and the prevention of HIV transmission. J Infect Dev Ctries.2008;2:328-334.

207. Giguère K, Vaziri M, Olivier C, et al. Characteristics of new HIV diagnoses over 1995-2019: A clinic-based study in Montréal, Canada. PLoS One.2021;16(10):e0258383.

208. Morris BJ, Krieger JN. Re: Circumcision and risk of HIV among males from Ontario, Canada. Letter. J Urol;Epub ahead of print Nov 15, 2021: 101097JU0000000000002337.

209. Nayan M, Hamilton RJ, Juurlink DN, Austin PC, Jarvi KA. Circumcision and risk of HIV among males from Ontario, Canada. J Urol.2021;Epub ahead of print Sep 23, 2021:101097ju0000000000002234.

210. Frisch M, Simonsen J. Non-therapeutic male circumcision in infancy or childhood and risk of human immunodeficiency virus and other sexually transmitted infections: national cohort study in Denmark. Eur J Epidemiol.2021.

211. Wiswell TE, Geschke DW. Risks from circumcision during the first month of life compared with those for uncircumcised boys. Pediatrics.1989;83(6):1011-1015.

212. Earp BD, Sardi LM, Jellison WA. False beliefs predict increased circumcision satisfaction in a sample of US American men. Cult Health Sex.2018;20(8):945-959.

213. Moreton S. Do false beliefs predict increased circumcision satisfaction in men? Adv Sex Med.2020;10:41-55.

214. How circumcision broke the Internet. Slate. Sep 18, 2013.

http://www.slate.com/articles/health_and_science/medical_examiner/2013/09/intactivists_online_a_fringe_ group_turned_the_internet_against_circumcision.html (accessed Apr 11, 2020)

215. Bailis SA, Moreton S, Morris BJ. Critical evaluation of a survey claiming "Long-term adverse outcomes from neonatal circumcision". Adv Sex Med.2019;9:67-109.

216. Tan HM, Tong SF, Ho CC. Men's health: sexual dysfunction, physical, and psychological health-is there a link? J Sex Med.2012;9(3):663-671.

217. Alexander SE, Storm DW, Cooper CS. Teasing in school locker rooms regarding penile appearance. J Urol.2015;193(3):983-987.

218. Stenram A, Malmfors G, Okmian L. Circumcision for phimosis-indications and results. Acta Paediatr Scand.1986;75(2):321-323.

219. Machmouchi M, Alkhotani A. Is neonatal circumcision judicious? Eur J Pediatr Surg.2007;17(4):266-269.

220. Weiss HA, Larke N, Halperin D, Schenker I. Complications of circumcision in male neonates, infants and children: a systematic review. BMC Urol.2010;10:article 2.

221. Collin L, Reisner SL, Tangpricha V, Goodman M. Prevalence of transgender depends on the "case" definition: A systematic review. J Sex Med.2016;13(4):613-626.

222. Garcia MM. Men's health and transgender surgery: a urologist's perspective. Translational andrology and urology.2016;5(2):225-227.

223. Carmack A, Notini L, Earp BD. Should surgery for hypospadias be performed before an age of consent? J Sex Res.2016;53(8):10471058.

224. Schlomer B, Breyer B, Copp H, Baskin L, DiSandro M. Do adult men with untreated hypospadias have adverse outcomes? A pilot study using a social media advertised survey. J Pediatr Urol.2014;10(4):672-679.

225. Banieghbal B. Optimal time for neonatal circumcision: an observation-based study. J Pediatr Urol.2009;5(5):359-362.

226. Frisch M, Earp BD. Circumcision of male infants and children as a public health measure in developed countries: A critical assessment of recent evidence. Glob Public Health.2018;13(5):626-641.

Page 22/26 
227. Folaranmi SE, Corbett HJ, Losty PD. Does application of topical steroids for lichen sclerosus (balanitis xerotica obliterans) affect the rate of circumcision? A systematic review. J Pediatr Surg.2018;53(11):2225-2227.

228. Dave S, Afshar K, Braga LH, Anderson P. Canadian Urological Association guideline on the care of the normal foreskin and neonatal circumcision in Canadian infants (full version). Can Urol Assoc J.2018;12(2):E76-e99.

229. Kirtschig G, Becker K, Gunthert A, et al. Evidence-based (S3) Guideline on (anogenital) lichen sclerosus. J Eur Acad Dermatol Venereol.2015;29(10):e1-43.

230. Green PA, Bethell GS, Wilkinson DJ, Kenny SE, Corbett HJ. Surgical management of genitourinary lichen sclerosus et atrophicus in boys in England: A 10-year review of practices and outcomes. J Pediatr Urol.2019;15(1):45 e41-45 e45.

231. Hotonu S, Mohamed A, Rajimwale A, Gopal M. Save the foreskin: Outcomes of preputioplasty in the treatment of childhood phimosis. Surgeon.2020;18(3):150-153.

232. Long SS. Can lumbar puncture be deferred in febrile neonates with suspected UTI? J Pediatr.2017;184:3.

233. Pallett A, Hand K. Complicated urinary tract infections: practical solutions for the treatment of multiresistant Gram-negative bacteria. The Journal of antimicrobial chemotherapy.2010;65 Suppl 3:iii25-33.

234. Fasugba O, Gardner A, Mitchell BG, Mnatzaganian G. Ciprofloxacin resistance in community- and hospital-acquired Escherichia coli urinary tract infections: a systematic review and meta-analysis of observational studies. BMC Infect Dis.2015;15(1):545.

235. Bryce A, Hay AD, Lane IF, Thornton HV, Wootton M, Costelloe C. Global prevalence of antibiotic resistance in paediatric urinary tract infections caused by Escherichia coli and association with routine use of antibiotics in primary care: systematic review and metaanalysis. BMJ.2016;352:i939.

236. Looke DFM, Thomas Gottlieb T, Jones CA, Paterson DL. Gram-negative resistance: can we combat the coming of a new "Red Plague"? Med J Aust.2013;198(5):243-244.

237. Wang J, He L, Sha J, et al. Etiology and antimicrobial resistance patterns in pediatric urinary tract infection. Pediatr Int.2018;60(5):418-422.

238. Mayor S. Test urine before prescribing antibiotics for most UTIs, says NICE. BMJ.2018;361:k2076.

239. Arshad M, Seed PC. Urinary tract infections in the infant. Clin Perinatol.2015;42(1):17-28, vii.

240. Anyanwu LJ, Kashibu E, Edwin CP, Mohammad AM. Microbiology of smegma in boys in Kano, Nigeria. J Surg Res.2012;173(1):2125.

241. Ladenhauf HN, Ardelean MA, Schimke C, Yankovic F, Schimpl G. Reduced bacterial colonisation of the glans penis after male circumcision in children-a prospective study. J Pediatr Urol.2013;9(6 Pt B):1137-1144.

242. Serour F, Samra Z, Kushel Z, Gorenstein A, Dan M. Comparative periurethral bacteriology of uncircumcised and circumcised males. Genitourin Med.1997;73(4):288-290.

243. Liu CM, Hungate BA, Tobian AA, et al. Male circumcision significantly reduces prevalence and load of genital anaerobic bacteria. mBio.2013;4(2):e00076.

244. Morris BJ, Krieger JN. Male circumcision does not reduce sexual function, sensitivity or satisfaction. Adv Sex Med.2015;5(2):53-60.

245. Lying. In: Circfacts.org. Real Facts About Male Circumcision. 2019. http://circfacts.org/cyber-bullying/\#cyber10 (accessed Nov 18, 2021)

246. MRI scans and circumcision brain damage. The lie that just won't die. In: Circfacts.org. Real Facts About Male Circumcision. 2019. http://circfacts.org/debunking-corner/\#debk4 (accessed Nov 18, 2021)

247. Anonymous. The challenge of the post-truth era. Nat Cell Biol.2018;20(11):1231.

248. Daniel Patrick Moynihan quotes. Good Reads. 2021. https://www.goodreads.com/author/quotes/219349.Daniel_Patrick_Moynihan (accessed 17 June 2021)

249. Eisenberg ML, Galusha D, Kennedy WA, Cullen MR. The relationship between neonatal circumcision, urinary tract infection, and health. World J Mens Health.2018;36(3):176-182.

250. Lewis EN, Griffin MR, Szilagyi PG, Zhu Y, Edwards KM, Poehling KA. Childhood influenza: number needed to vaccinate to prevent 1 hospitalization or outpatient visit. Pediatrics.2007;120(3):467-472.

251. Koyle MA, Barqawi A, Wild J, Passamaneck M, Furness PD, 3rd. Pediatric urinary tract infections: the role of fluoroquinolones. Pediatr Infect Dis J.2003;22(12):1133-1137.

252. Swerkersson S, Jodal U, Sixt R, Stokland E, Hansson S. Urinary tract infection in small children: the evolution of renal damage over time. Pediatr Nephrol.2017;32(10):1907-1913.

Page 23/26 
253. Millard PS, Goldstuck N. Legality of circumcision in South Africa. S Afr Med J.2013;103(7):436.

254. Hainz T. The enhancement of children versus circumcision: A case of double moral standards? Bioethics.2015;29(7):507-515.

255. Kabwama SN, Ssewanyana D, Berg-Beckhoff G. The association between male circumcision and condom use behavior - a metaanalysis. Mater Sociomed.2018;30(1):62-66.

256. Gao Y, Yuan T, Zhan Y, et al. Association between medical male circumcision and HIV risk compensation among heterosexual men: a systematic review and meta-analysis. Lancet Glob Health.2021;9(7):e932-e941.

257. Morris BJ, Flanagan JL, McKinnon KJ, Nightingale BN. Papillomavirus screening of cervical lavages by polymerase chain reaction. Lancet.1988;ii(8624):1368.

https://www.researchgate.net/publication/20252344_Papillomavirus_screening_of_cervical_lavages_by_polymerase_chain_reaction. (accessed Jul 20, 2021)

258. Morris BJ. The advent of human papillomavirus detection for cervical screening. Curr Opin Obstet Gynecol 2019;31(5):333-339.

259. Robinson JL, Jefferies A, Lacaze T. Letter to the Editor - Re: Canadian Pediatrics Society position statement on newborn circumcision: a risk-benefit analysis revisited. Can J Urol.2017;24(1):8684-8687.

260. Public Health Agency of Canada. Canadian National Report on Immunization, 2006. Volume 32S3. Section 5. Vaccine Safety: Surveilance of Adverse Events Following Immunization. http://www.phac-aspc.gc.ca/publicat/ccdr-rmtc/06vol32/32s3/5vacceng.php (accessed Nov 2, 2021)

261. Canadian Cancer Statistics 2016.

http://www.cancer.ca/ /media/cancer.ca/CW/cancer\%20information/cancer\%20101/Canadian\%20cancer\%20statistics/CanadianCancer-Statistics-2016-EN.pdf?la=en (accessed Oct 14, 2021)

262. Centers for Disease Control and Prevention. [Docket No. CDC-2014-0012-0001] Recommendations for Providers Counseling Male Patients and Parents Regarding Male Circumcision and the Prevention of HIV Infection, STIs, and Other Health Outcomes. Federal Register, vol. 79, No. 231, 71433. 2014. https://www.federalregister.gov/documents/2014/12/02/2014-27814/recommendations-forproviders-counseling-male-patients-and-parents-regarding-male-circumcision-and (accessed Jun 15, 2021).

263. Centers for Disease Control and Prevention. [Docket No. CDC-2014-0012-0002] Recommendations for Providers Counseling Male Patients and Parents Regarding Male Circumcision and the Prevention of HIV Infection, STIs, and Other Health Outcomes. 2014. http://www.regulations.gov/\#!documentDetail;D=CDC-2014-0012-0002 (accessed uly 16, 2021).

264. Morris BJ. Commentary: Do the benefits of male circumcision outweigh the risks? A critique of the proposed CDC guidelines. Front Pediatr.2015;3:article 88.

265. Morris BJ, Krieger JN, Klausner JD. CDC's male circumcision recommendations represent a key public health measure. Glob Health Sci Pract.2017;5(1):15-27.

266. Centers for Disease Control and Prevention. Peer Review Comments and CDC Responses for Information for Providers Counseling Male Patients and Parents Regarding Male Circumcision and the Prevention of HIV infection, Sexually Transmitted Infections, and other Health Outcomes* and Background, Methods, and Synthesis of Scientific Information Used to Inform "Information for Providers to Share with Male Patients and Parents Regarding Male Circumcision and the Prevention of HIV Infection, Sexually Transmitted Infections, and other Health Outcomes". 2018. https://www.cdc.gov/hiv/pdf/risk/MC-HISA-Round-1-Peer-ReviewComments-and-Responses.pdf (accessed Jul 16, 2021)

267. Centers for Disease Control and Prevention. Summary of Public Comments and CDC Responses to Public Comments for Information for Providers Counseling Male patients and Parents Regarding Male Circumcision and the Prevention of HIV Infection, Sexually Transmitted Infections, and Other Health Outcomes. 2018. https://www.cdc.gov/hiv/pdf/risk/MC-HISA-Public-Comments-andResponses.pdf

268. Sorokan ST, Finlay JC, Jeffries AL. Newborn male circumcision. Position Statement. Canadian Paediatric Society. Paediatr Child Health.2015;20:311-315.

269. British Medical Association. Non-therapeutic male circumcision of children toolkit. https://www.bma.org.uk/advice/employment/ethics/children-and-young-people/non-therapeutic-male-circumcision-of-childrenethics-toolkit (accessed Oct 3, 2021)

270. Royal Australasian College of Physicians, Paediatrics \& Child Health Division. Circumcision of infant males. http://www.racp.edu.au/index.cfm?objectid=65118B16-F145-8B74-236C86100E4E3E8E (accessed Oct 18, 2021)

271. Morris BJ, Wodak AD. Causes and consequences of the decline in circumcision in Australia. ANZ J Surg.2021; 91(11):2546-2547. 
272. Morris BJ, Wodak AD, Mindel A, et al. The 2010 Royal Australasian College of Physicians policy statement 'Circumcision of infant males' is not evidence based. Intern Med J.2012;42(7):822-828.

273. Danish Medical Association. Lægeforeningens politik vedrørende omskæring afdrengebørn uden medicinsk indication. 2016 https://www.laeger.dk/laegeforeningens-politik-vedroerende-omskaering-af-drengeboern-uden-medicinsk-indikation (accessed 21 Jun 2021)

274. Green LW, McAllister RG, Peterson KW, Travis JW. Medicaid coverage of circumcision spreads harm to the poor. Am J Public Health.2009;99(4):584; author reply 584-586.

275. Hill G, Boyle GJ, Geisheker JV. 'Circumcision of infant males' must warn doctors of possible criminal assault charges. Intern Med J.2012;42(11):1280-1281.

276. Svoboda JS. Circumcision is a religious/cultural procedure, not a medical procedure. JAMA Pediatr.2014;168(3):293-294.

277. Morris BJ, Tobian AA. Circumcision is a religious/cultural procedure, not a medical procedure-reply. JAMA Pediatr.2014;168(3):294.

278. Morris BJ, Krieger JN, Rivin BE. The ethical course is to recommend infant male circumcision - Arguments disparaging American Academy of Pediatrics affirmative policy do not withstand scrutiny. J Law Med Ethics.2017;45:647-663.

\section{Tables}

Due to technical limitations, tables are only available as a download in the Supplemental Files section.

\section{Figures}




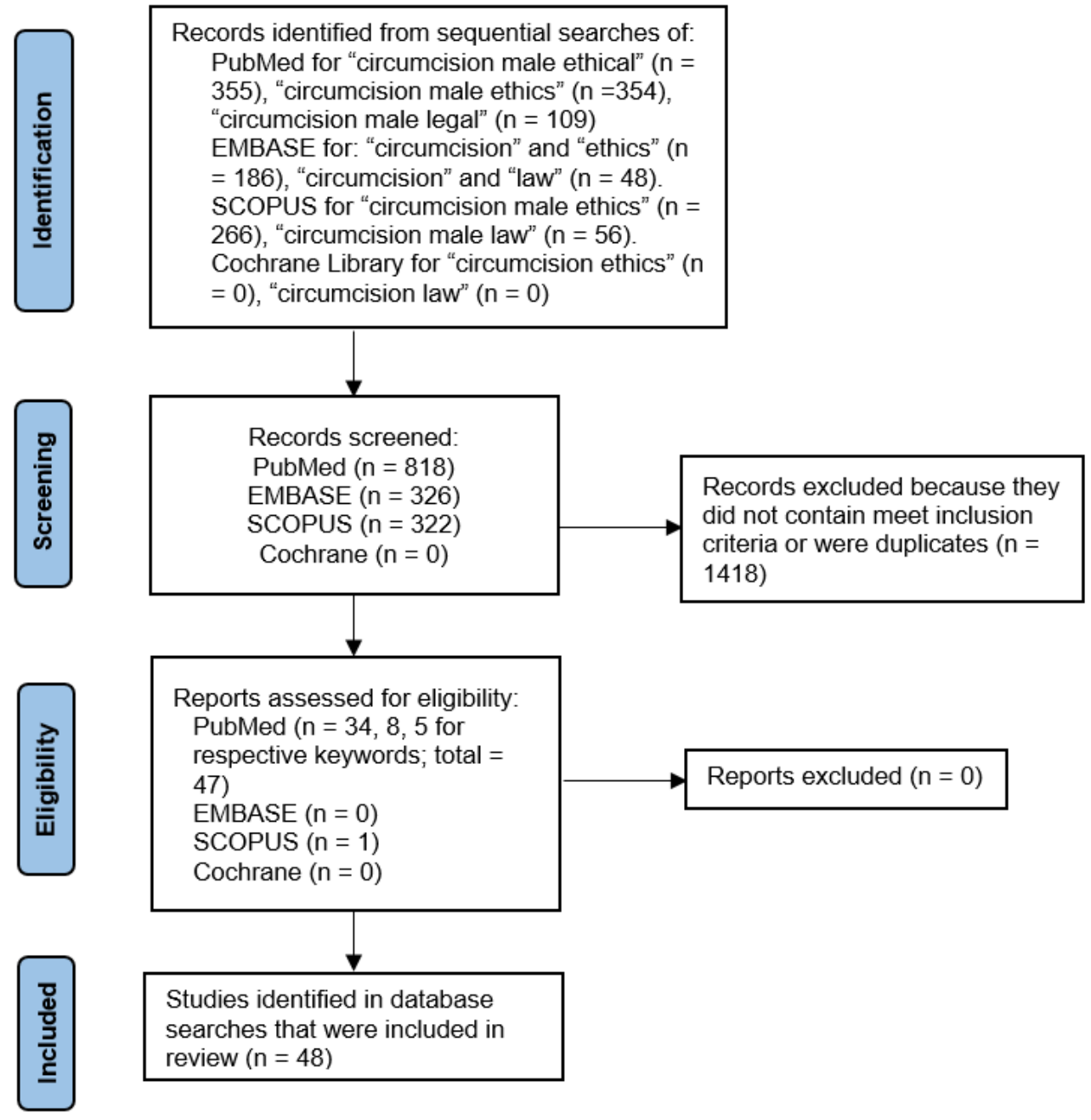

Figure 1

Search strategy diagram as required by PRISMA guidelines. Flowchart shows identification, review, and selection of studies relevant to the study.

\section{Supplementary Files}

This is a list of supplementary files associated with this preprint. Click to download.

- Table1.docx

- Table2.docx

- Table3.docx 